\title{
Microglia Protect Neurons against Ischemia by Synthesis of Tumor Necrosis Factor
}

\author{
Kate Lykke Lambertsen, ${ }^{1}$ Bettina Hjelm Clausen, ${ }^{1}$ Alicia Anne Babcock, ${ }^{1}$ Rikke Gregersen, ${ }^{1}$ Christina Fenger, ${ }^{1}$ \\ Helle Hvilsted Nielsen, ${ }^{1}$ Laila Skov Haugaard, ${ }^{1,2}$ Martin Wirenfeldt, ${ }^{1}$ Marianne Nielsen, ${ }^{3}$ Frederik Dagnaes-Hansen, ${ }^{4}$ \\ Horst Bluethmann, ${ }^{5}$ Nils Joakim Færgeman, ${ }^{2}$ Michael Meldgaard, ${ }^{1}$ Tomas Deierborg, ${ }^{6}$ and Bente Finsen ${ }^{1}$ \\ ${ }^{1}$ Medical Biotechnology Center and Departments of ${ }^{2}$ Biochemistry and Molecular Biology and ${ }^{3}$ Anatomy and Neurobiology, University of Southern \\ Denmark, 5000 Odense, Denmark, ${ }^{4}$ Department of Medical Microbiology and Immunology, University of Aarhus, 8000 Aarhus, Denmark, ${ }^{5}$ Transgenic \\ Animal Models, F. Hoffmann-La Roche 93/614, CH-4070 Basel, Switzerland, and 'Laboratory of Experimental Brain Research, Lund University, 22184 \\ Lund, Sweden
}

Microglia and infiltrating leukocytes are considered major producers of tumor necrosis factor (TNF), which is a crucial player in cerebral ischemia and brain inflammation. We have identified a neuroprotective role for microglial-derived TNF in cerebral ischemia in mice. We show that cortical infarction and behavioral deficit are significantly exacerbated in TNF-knock-out (KO) mice compared with wild-type mice. By using in situ hybridization, immunohistochemistry, and green fluorescent protein bone marrow (BM)-chimeric mice, TNF was shown to be produced by microglia and infiltrating leukocytes. Additional analysis demonstrating that BM-chimeric TNF-KO mice grafted with wild-type BM cells developed larger infarcts than BM-chimeric wild-type mice grafted with TNF-KO BM cells provided evidence that the neuroprotective effect of TNF was attributable to microglial- not leukocyte-derived TNF. In addition, observation of increased infarction in TNF-p55 receptor (TNF-p55R)-K0 mice compared with TNF-p75R and wild-type mice suggested that microglialderived TNF exerts neuroprotective effects through TNF-p55R. We finally report that TNF deficiency is associated with reduced microglial population size and Toll-like receptor 2 expression in unmanipulated brain, which might also influence the neuronal response to injury. Our results identify microglia and microglial-derived TNF as playing a key role in determining the survival of endangered neurons in cerebral ischemia.

Key words: cytokines; neurodegeneration; knock-out mice; chimeric mice; neuroprotection; behavior

\section{Introduction}

Activated, resident microglia and blood-derived leukocytes are considered major sources of the proinflammatory and neuromodulatory cytokine tumor necrosis factor (TNF) after experimental stroke (Gregersen et al., 2000; Hallenbeck, 2002; Lambertsen et al., 2005). TNF is also implicated in ischemic stroke and trauma in humans (Zaremba and Losy, 2001) where it, similar to mouse (Gregersen et al., 2000; Lambertsen et al., 2005), is produced by microglia and infiltrating leukocytes (Dziewulska and Mossakowski, 2003) and levels are elevated in CSF and serum

\footnotetext{
Received Nov. 12, 2008; accepted Dec. 19, 2008.

B.F. was supported by grants from the Lundbeck Foundation and The Danish Medical Research Council (MRC). K.L.L. was supported by grants from The Danish MRC, Fonden til Lægevidenskabens Fremme, Beckett Fonden, Augustinusfonden, Tømrermester Alfred Andersen og Hustru's Fond, Harboefonden, Aase og Ejnar Danielsens Fond, Kong Christian den X's Fond, Den Raben-Levetzauske Fond, Direktør Jacob Madsen og Hustru Olga Madsens Fond, Grosserer Valdemar Foersom og hustru Thyra Foersom født Otto's Fond, Direktør Kurt Bønnelycke og hustru Grethe Bønnelyckes Fond, Fhv. Dir. Leo Nielsen og Hustru Karen Magrethe Nielsens Legat for Lægevidenskabelig Grundforskning, Overlægerådets Legatudvalg, Carl og Ellen Hertz's Legat til Dansk Læge-og Naturvidenskab, Familien Hede Nielsens Fond, Else og Aage Grønbeck-0lsens Legat, P.A. Messerschmidt og Hustru's Fond, and A. J. Andersen og Hustrus Fond. We acknowledge Lene Jørgensen, Sussanne Petersen, Inger Nissen, Camilla Rasmussen, and The Laboratory of Biomedicine, University of Southern Denmark, Odense, Denmark for excellent technical assistance; and Prof. Tadeusz Wieloch (Lund University, Lund, Sweden) for facilitating the behavioral part of the study.

Correspondence should be addressed to Bente Finsen, Medical Biotechnology Center, Winsloewparken 25, 2, University of Southern Denmark, DK-5000 0dense C, Denmark. E-mail: bfinsen@health.sdu.dk.

DOI:10.1523/JNEUROSCI.5505-08.2009

Copyright $\odot 2009$ Society for Neuroscience $\quad$ 0270-6474/09/291319-12\$15.00/0
}

(Tarkowski et al., 1997; Sotgiu et al., 2006). Experimentally, TNF has both neuroprotective and neurotoxic effects. TNF is involved in ischemic tolerance induction, a phenomenon in which pharmacological intervention or short episodes of cerebral ischemia make neurons resistant to a subsequent ischemic insult (Nawashiro et al., 1997; Pradillo et al., 2005), and is neuroprotective in focal cerebral ischemia (Bruce et al., 1996; Gary et al., 1998) and acute excitotoxicity (Marchetti et al., 2004; Turrin and Rivest, 2006). Most studies suggest that TNF is neuroprotective via TNF-p55 receptor (TNF-p55R) (Bruce et al., 1996; Gary et al., 1998; Taoufik et al., 2008), although neuroprotection through TNF-p75R has also been reported (Fontaine et al., 2002; Marchetti et al., 2004). In contrast, TNF has been shown to enhance ischemic tissue damage after focal cerebral ischemia (Barone et al., 1997; Wang et al., 2004). Although conflicting, these observations demonstrate that TNF plays a key role in modulating neuronal sensitivity to focal cerebral ischemia.

Permanent focal cerebral ischemia is a commonly used model for ischemic stroke in rodents. In this model, TNF mRNA and protein levels are elevated $4-6 \mathrm{~h}$ after the ischemic insult (Liu et al., 1994; Buttini et al., 1996; Gregersen et al., 2000; Lambertsen et al., 2005), which is within the therapeutic window where the size of ischemic tissue damage can still be manipulated (Barone et al., 1997; Wang et al., 2001). In the ischemic mouse brain, we have 
previously shown that TNF is produced by microglia and bloodderived leukocytes (Gregersen et al., 2000; Lambertsen et al., 2005). However, whereas the TNF-producing leukocytes inevitably infiltrate the infarct after induction of the ischemic insult (Priller et al., 2001; Clausen et al., 2008), the resident microglial cells are already positioned to sense changes in neuronal function and viability within the infarct and surrounding penumbra. Because TNF can modulate synaptic strength and plasticity (Beattie et al., 2002; Stellwagen and Malenka, 2006), this implicates microglia as mediators of neural physiology in normal CNS. Furthermore, it suggests that microglial-derived TNF might also modulate neuronal sensitivity to ischemia.

We examined the role of microglial- and leukocyte-derived TNF in neuroprotection/neurotoxicity after permanent middle cerebral artery occlusion (pMCAo) in mice. Using TNF-knockout $(\mathrm{KO})$ mice, and bone marrow (BM)-chimeric mice lacking either microglial- or leukocyte-derived TNF, we found that microglial-derived TNF reduced the size of the cortical infarcts and behavioral deficits and modulated inflammatory responses after focal cerebral ischemia in mice. In addition, using mice deficient in either of the two TNF receptors, TNF-p55 and TNFp75, we showed the neuroprotective effect of microglial-derived TNF was mediated through TNF-p55R. Collectively, our findings argue that microglia, through synthesis of TNF, modulate the survival of endangered neurons in ischemically injured brain.

\section{Materials and Methods}

Mice. Adult (23-31 g) male TNF-KO, TNF-p55p75R-KO (both on a mixed C57BL/6 × 129S6 background), B6129SF2/J, C57BL/6, and C57BL/6$\mathrm{Tg}$ (UBC-GFP)30Scha/ mice were from The Jackson Laboratory. Adult male TNF-p55R-KO, TNF-p75R-KO, and TNF-p55p75R-KO mice and agematched C57BL/6x129 littermate mice were obtained from Hoffmann-La Roche. Additional C57BL/6 mice were from Taconic. All efforts were made to minimize pain and distress according to approvals by the Danish Animal Inspectorate (J. No. 2005/561-1068).

$B M$ chimeras. Irradiated recipients $\left(9.5 \mathrm{~Gy}\right.$ from a ${ }^{137} \mathrm{Cs}$ source $)$ were transplanted with $\sim 10^{7}$ donor BM cells into the lateral tail veins (Wirenfeldt et al., 2007). Recipients were given oxytetracycline (2 g/L Terramycin vet. $20 \%$; Pfizer) in autoclaved drinking water for $3 \mathrm{~d}$ and after that were supplied with acidified water, $\mathrm{pH} 3$. Mice were maintained in an isolator, fed irradiation-sterilized chow, and allowed 4-6 weeks of recovery before surgery.

Cerebrovascular anatomy. The circle of Willis and its branches were examined in TNF-KO and B6129 mice. Mice were overdosed with pentobarbital and perfused with $10 \mathrm{ml}$ of $0.9 \%$ saline, followed by $10 \mathrm{ml}$ of a $50 \%$ solution of Quink carbon black ink (SolvX; Parker). Vessels were photographed under a dissecting microscope. The left and right posterior communicating (PCOM) arteries were scored as follows: 0 , absent; 1 , present, but poorly developed (hypoplastic); 2, well formed. A single PCOM score was obtained by averaging left and right scores.

Focal cerebral ischemia. The distal part of the left MCA was permanently occluded under Hypnorm/Stesolid anesthesia [fentanyl citrate (0.315 mg/ml; Jansen-Cilag) and Fluanisone (10 mg/ml; Jansen-Cilag); and Diazepamum (5 mg/ml; Dumex), respectively] (Gregersen et al., 2000; Lambertsen et al., 2005). After surgery, mice were supplied with 1 $\mathrm{ml}$ of $0.9 \%$ saline and maintained in a $28^{\circ} \mathrm{C}$ controlled environment. Mice with $5 \mathrm{~d}$ survival were returned to the conventional animal facility after $24 \mathrm{~h}$. For postsurgical analgesia, mice were treated with Temgesic ( $0.001 \mathrm{mg} / 20 \mathrm{~g}$ buprenorphinum; Reckitt \& Colman) three times at $8 \mathrm{~h}$ intervals starting immediately after surgery.

Volumetric analysis. Mice were killed by cervical dislocation $24 \mathrm{~h}$ or $5 \mathrm{~d}$ after surgery. Brains were removed, frozen in $\mathrm{CO}_{2}$ snow, and cut into 30 $\mu \mathrm{m}$ sections. Every sixth section was stained with Toluidine blue for estimation of infarct volume using the Cavalieri principle (Gregersen et al., 2000). In addition, the volume of the contralateral and the nonischemic ipsilateral cortex and the volume of injury spanning from $1080 \mu \mathrm{m}$ anterior to $1080 \mu \mathrm{m}$ posterior of the anterior commissure was compared in TNF-KO, C57BL/6 and B6129 mice using an indirect method of infarct volume estimation (Lin et al., 1993).

Behavioral analysis. The stroke-lesion induced by pMCAo in mouse (Lambertsen et al., 2005) affects cortical brain areas controlling the contralateral front limb/paw and hindlimb/paw (Pronichev and Lenkov, 1998). We analyzed the grip strength in individual paws to measure the severity of the pMCAo-induced asymmetry. We assessed the grip strength in the ipsilateral and contralateral front paw and hindpaw before and 3 and $5 \mathrm{~d}$ after surgery in TNF-KO and C57BL/6 mice using a grip strength tester (BIO-GT-3; Bioseb) (Gao et al., 2008). We also used the rotating pole test (Nygren and Wieloch, 2005) and footprint analysis (Fiore et al., 2004).

Immunohistochemistry. Mice were overdosed with pentobarbital and perfused with $10 \mathrm{ml}$ of Soerensens buffer (SB) followed by cold 4\% PFA (PFA) in SB (Lambertsen et al., 2007). Brain and spleen were removed, along with the heart, kidney, and liver, in subsets of mice. Organs were postfixed, frozen, and processed into $16 \mu \mathrm{m}$ cryostat sections. Antibodies used for staining were rat anti-mouse TNF (Endogen), rabbit anti-mouse TNF (Endogen), rat anti-mouse CD11b (Serotec), biotinylated mouse anti-NeuN (Millipore Bioscience Research Reagents), rat anti-mouse Gr-1 (Ly-6G and Ly-6C; Serotec), rabbit anti-caspase 3 (Cell Signaling Technology), and rabbit anti-p-NF $\kappa$ B p65 (Ser536) (Santa Cruz Biotechnology). Isotype control antibodies were rabbit IgG (DakoCytomation), rat IgG1 (Hybridomus), biotinylated mouse IgG1 (Invitrogen), and rat $\operatorname{IgG} 2_{\mathrm{b}}$ (Biosite). The secondary fluorochrome-conjugated goat antirabbit IgG, chicken anti-rabbit IgG, streptavidin, and goat anti-rat IgG were purchased from Invitrogen, whereas donkey anti-rabbit was from FluoProbes. Sections were stained as described by Lambertsen et al. (2007) and mounted in ProLong Gold antifade reagent with 4',6diamidino-2-phenylindole (DAPI; Invitrogen). In fresh-frozen sections, TNF was detected using alkaline phosphatase (AP)-conjugated antirabbit antibody (Sigma-Aldrich) (Lambertsen et al., 2005). Substitution of the primary antibody with isotype control or rabbit IgG gave no signal.

Detection of TNF mRNA by in situ hybridization. Detection of TNF mRNA was performed using a mixture of three AP-labeled DNA probes $(6 \mathrm{pmol} / \mathrm{ml})$, designed by use of Oligo-design software version 6.0 and fabricated by DNA Technology complementary to bases 305-332 (CTTCTCATCCCTTTGGGGACCGATCACC), 570-597 (GTAGTCGGGGCAGCCTTGTCCCTTGAA), and 657-684 (CTTGACGGCAGAGAGGAGGTTGACTTTC), respectively, of murine TNF mRNA. The hybridization was performed on 30- $\mu \mathrm{m}$-thick ethanol-fixed sections using the protocol by Lambertsen et al. (2005). The hybridization signal was developed using an AP buffer containing 5-bromo-4-chloro-3indolyl phosphate and nitroblue tetrazolium, giving rise to a purple reaction product. The specificity of the hybridizations was documented by the following: (1) presence of an increased signal when sections were hybridized with all three probes compared with one or two probes; (2) abolishment of the hybridization signal when hybridizing RNase A (Pfizer)-digested sections, or when hybridizing sections with a 100-fold excess of the unlabeled probe mixture; and (3) absence of signal in sections incubated with buffer only. As done routinely, parallel sections were hybridized for the widely expressed glyceraldehyde-3-phosphate dehydrogenase mRNA to ensure the overall suitability of the tissue for hybridization (Lambertsen et al., 2005).

Combined in situ hybridization and immunohistochemistry. Sections were subjected to the standard in situ hybridization procedure. Sections were then rinsed $15 \mathrm{~min}$ in TBS buffer containing $1 \%$ Triton X-100 and incubated with biotinylated mouse anti-NeuN $(5 \mu \mathrm{g} / \mathrm{ml})$ or biotinylated mouse IgG1 isotype control $(5 \mu \mathrm{g} / \mathrm{ml})$ in TBS buffer plus $10 \%$ bovine serum for $4 \mathrm{~h}$, followed by rinsing three times for $15 \mathrm{~min}$ in TBS buffer containing 1\% Triton X-100 and incubation with Alexa 488-conjugated streptavidin $(5 \mu \mathrm{g} / \mathrm{ml})$ for $1 \mathrm{~h}$. After a final rinse in TBS, sections were counterstained with DAPI nuclear staining. The color of bright-field pictures of the in situ hybridization signal was inverted, and the in situ signal was recolored with red using Adobe Photoshop software.

Quantitative PCR. The brain was rapidly removed from the decapitated mouse. The brainstem was transected at the level of the superior colliculi, and ipsilateral and contralateral hemispheres were immersed in RNAlater Stabilization Reagent (Qiagen) for total RNA extraction and 
cDNA synthesis as described previously (Clausen et al., 2005). Quantitative PCR was performed on an iCycler (Bio-Rad) with published primer and probe sequences (Clausen et al., 2005; Lambertsen et al., 2007), except for TNF mRNA (primer set, TCTTCTCATTCCTGCTTGTGGC and AGGCCATTTGGGAACTTCTCATC; probe sequence, CCACCACGCTCTTCTGTCTACTGAACTTCGG), inducible nitric oxide synthase (iNOS) mRNA (primer set, GGACAGCACAGAATGTTCCAGAA and CAAAATCTCTCCACTGCCCCAG), and Toll-like receptor 2 (TLR2) mRNA (primer set, AAACCTCAGACAAAGCGTCAAATC and GTTTGCTGAAGAGGACTGTTATG), with the latter two performed using SYBR Green instead of TaqMan probes (Wirenfeldt et al., 2007). Values were normalized to HPRT1 as the reference gene and calibrated to a pool of cDNA from unmanipulated C57BL/6 mice. Transcript levels within twofold threshold of methodological resolution were not subjected to statistical analysis (Meldgaard et al., 2006).

Flow cytometry. The ipsilateral and contralateral cortices were dissected from PBS-perfused CNS. Blood samples were collected from BMchimeric mice for validation of chimerism as described previously (Wirenfeldt et al., 2007). Single-cell suspensions were obtained by homogenization through $70 \mu \mathrm{m}$ nylon cell strainers (BD Falcon) in RPMI medium containing 10\% FCS and blocked and stained for surface markers as described previously (Babcock et al., 2006; Wirenfeldt et al., 2007). For tissues intended for intracellular staining, $1 \mu \mathrm{l} / \mathrm{ml} \mathrm{BD}$ GolgiPlug with brefeldin A (BD Biosciences) was included during dissociation and incubation, which took place at $37^{\circ} \mathrm{C}$ with $5 \% \mathrm{CO}_{2}$ for $4.5 \mathrm{~h}$ without additional stimulation. Antibodies purchased from BD Biosciences were rat anti-mouse CD11b (M1/70), rat anti-mouse CD45 (30-F11), hamster anti-mouse T-cell receptor (TCR $\beta)(\mathrm{H} 57-597)$, hamster anti-mouse TNF (TN3-19.12), and rat anti-mouse Gr-1 (Ly-6G and Ly6C; RB6$8 \mathrm{C} 5$ ), as well as rat $\operatorname{IgG} 2_{\mathrm{b}}$ (A95-1), hamster IgG2 (B81-3), and hamster IgG1 (G235-2356) as isotype controls and allophycocyanin-conjugated streptavidin. Biotinylated rat anti-mouse TLR2 (6C2) was from eBioscience. After staining of surface markers, cells intended for TNF staining were fixed in Cytofix/Cytoperm (BD Biosciences) for $20 \mathrm{~min}$ at $4^{\circ} \mathrm{C}$, washed in $1 \mathrm{ml}$ of $1 \times$ PermWash buffer (BD Biosciences), and incubated with an antibody against TNF (or isotype control) for $30 \mathrm{~min}$, followed by resuspension in staining buffer. Cells only stained for surface antigens were fixed with $4 \%$ paraformaldehyde (PFA) directly after staining and resuspended in staining buffer. Samples were analyzed using a FACSCalibur flow cytometer and CellQuest Pro software (BD Biosciences) (Babcock et al., 2006; Wirenfeldt et al., 2007). Positive staining was determined based on fluorescence levels of isotype controls or autofluorescence controls [for green fluorescent protein (GFP)]. For analysis of macrophages/granulocytes and microglia, cells were gated on side scatter (SSC) versus CD11b, followed by forward scatter (FSC) versus CD11b and FSC versus CD45. Microglia were separated from leukocytes based on CD45 expression, with intermediate levels of CD45 (CD45 dim) identifying CD $11 b^{+}$microglia and high levels of CD45 (CD45 ${ }^{\text {high }}$ ) identify-

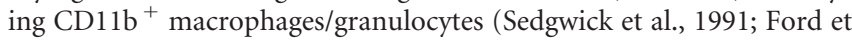
al., 1995). $\mathrm{GFP}^{+}, \mathrm{TNF}^{+}, \mathrm{TLR}^{+}{ }^{+}$, and $\mathrm{Gr}-1^{+}$cells were identified on additional channels. Granulocytes were distinguished from macrophages based on expression of Gr-1. T-cells were identified as TCR $\beta^{+} \mathrm{CD} 45^{\text {high }}$, after gating on SSC versus CD45 and FSC versus CD45 (Babcock et al., 2006). Mean numbers of cells were estimated using previously described methods (Babcock et al., 2006; Wirenfeldt et al., 2007; Clausen et al., 2008).

Preparation of cellular extracts and Western blotting. Total and nuclear extracts were prepared essentially according to Crack et al. (2006), except that $1 \times$ protease inhibitor cocktail (Roche Applied Science) was added to the buffers used and that protein concentrations were estimated using the Qubit Protein Assay according to the manufacturer (Invitrogen). Western blot analysis was performed using 25 and $50 \mu \mathrm{g}$ of nuclear extract and supernatant, respectively, separated on 10\% SDS-PAGE gels. Proteins were transferred onto polyvinylidene difluoride blotting membranes (Bio-Rad) by electroblotting and blocked overnight at $4^{\circ} \mathrm{C}$ in TBS plus Triton X-100 containing 5\% skim milk. Membranes were incubated in TBS plus Triton X-100/milk containing either anti-nuclear factor $-\kappa \mathrm{B}$ (NF- $\kappa$ B) p65 (Ser536) or anti-transcription factor II B (TFIIB) (Santa Cruz Biotechnology) antibodies for $1 \mathrm{~h}$. Membranes were washed three times in TBS plus Triton X-100 and incubated with secondary antibodies
(HRP-conjugated anti-rabbit IgG or anti-mouse IgG; Promega) for $1 \mathrm{~h}$. After washing, proteins were visualized using enhanced chemiluminescence as described by the manufacturer (GE Healthcare).

Counting of caspase $-3^{+}$and $N F-\kappa B^{+}$cells. The number of activated caspase $-3^{+}$and NF- $\kappa \mathrm{B}^{+}$cells was counted in TNF-KO and C57BL/6 mice $24 \mathrm{~h}$ after pMCAo. The infarct was outlined, and cells with a clear cytoplasmatic immunoreactivity for activated caspase- 3 and a clear nuclear expression of NF- $\kappa \mathrm{B}$ were counted on four to five sections from each animal using a $100 \times$ objective and a $38 \%$ counting frame area stepping $200 \mu \mathrm{m} / 200 \mu \mathrm{m}$ in the $X Y$-position using the CAST Grid System (Olympus). The average number of cells per square millimeter was calculated for each animal.

Data analysis. Quantitative data are presented as means \pm SD. Comparison of means in two groups was performed using the Mann-Whitney rank sum test. Comparison of mRNA level data was performed using one-way ANOVA followed by Dunnett's multiple comparison test. For multiple comparisons, Kruskal-Wallis one-way ANOVA and a follow-up test were used. Behavioral analysis was performed using the $\chi^{2}$ test or Student's $t$ test. Statistical analyses were performed using Prism 4.0b software for Macintosh (GraphPad Software). Statistical significance was established for $p<0.05$.

\section{Results}

TNF synthesis is induced within the first critical hours in focal cerebral ischemia

Focal cerebral ischemia induced by pMCAo results in cortical infarction and is accompanied by activation of resident $\mathrm{CD} 11 \mathrm{~b}^{+}$ microglia and infiltration of $\mathrm{CD}_{1} \mathrm{~b}^{+}$leukocytes in the infarct and penumbra (Fig. 1A). Quantitative PCR showed that TNF mRNA levels were significantly upregulated in the ischemic hemisphere of C57BL/6 mice by $6 \mathrm{~h}$ and reached peak levels 12-24 h after pMCAo (Fig. $1 B$ ), as reported previously in SJL mice (Lambertsen et al., 2005). No TNF mRNA was detected in TNF-KO mice. We next used in situ hybridization to determine the topology of the cells expressing TNF mRNA. We applied a protocol with increased sensitivity allowing us to detect distinctly labeled TNF mRNA ${ }^{+}$cells from $4 \mathrm{~h}$ after pMCAo (Fig. 2). Interestingly, at $4 \mathrm{~h}$ the cells induced to express TNF mRNA showed a predeliction for layers II and III of the cingulate gyrus, whereas the TNF $\mathrm{mRNA}^{+}$cells were widely distributed throughout the ipsilateral cortex $6 \mathrm{~h}$ after pMCAo. In comparison, the more highly TNF mRNA $^{+}$cells present 12 and $24 \mathrm{~h}$ after pMCAo located to the penumbra and the infarct (Fig. 2), as reported previously for C57BL/6 mice (Gregersen et al., 2000).

The in situ hybridization results were supported by immunohistochemistry showing abundant $\mathrm{TNF}^{+}$cells in the penumbra and infarct at 12 and $24 \mathrm{~h}$ (data not shown), which by doubleimmunofluorescence staining were identified as $\mathrm{TNF}^{+} \mathrm{CD}_{11 b^{+}}$ microglia/leukocytes (Fig. $1 E$ and data not shown). We also looked for neuronal and astroglial synthesis of TNF in our model. Overall, the TNF $\mathrm{mRNA}^{+}$cells had small round to elongated nuclei characteristic of microglial cells or macrophages (Fig. 2). This was supported by absence of colocalization of TNF mRNA to $\mathrm{NeuN}^{+}$neurons at $6 \mathrm{~h}$ and TNF protein to $\mathrm{NeuN}^{+}$neurons at $24 \mathrm{~h}$ (Fig. 1C,D). In line with previous observations in C57BL/6 and SJL mice (Gregersen et al., 2000; Lambertsen et al., 2005), we failed to show colocalization of TNF and TNF mRNA to GFAP ${ }^{+}$ astrocytes (data not shown). Together, the data strongly suggest that resident microglia and infiltrating leukocytes were the sources of the elevated levels of TNF after pMCAo in mice.

\section{TNF is expressed by microglia and infiltrating macrophages in focal cerebral ischemia}

To use a BM chimeric approach for subsequent determination of the impact of microglial- and leukocyte-derived TNF on infarct 
development, we next analyzed the TNF response of resident and infiltrating cells in BM-chimeric and nonchimeric mice subjected to pMCAo. For this experiment, we used C57BL/6 mice grafted with BM cells from GFP-transgenic mice. In these GFP-BM-chimeric mice, GFP was expressed by BM-derived cells in all organs investigated (heart, kidney, liver, spleen) except the brain, which is populated by relatively radio-resistant microglia (below). We could therefore track infiltration of $\mathrm{GFP}^{+} \mathrm{BM}$-derived leukocytes into the ischemically injured brain by inspecting sections from 6,12 , and $24 \mathrm{~h}$ after pMCAo $(n=3-5$ per group). $\mathrm{GFP}^{+} \mathrm{CD} 11 \mathrm{~b}{ }^{+} \mathrm{BM}$ cells were relatively few at $6 \mathrm{~h}$ but increased with time to reach maximum at $24 \mathrm{~h}$ (Fig. $3 A, 24 \mathrm{~h}$ ). Quantitative results obtained by flow cytometric analysis of cortex isolated from GFP-BM-chimeric mice showed that a significant lesion-specific recruitment of BMderived $\mathrm{GFP}^{+} \mathrm{CD} 11 \mathrm{~b}{ }^{+}$cells first occurred $24 \mathrm{~h}$ after pMCAo (Fig. 3C). As expected, the majority of the $\mathrm{CD} 11 \mathrm{~b}{ }^{+} \mathrm{CD} 45^{\text {high }}$ leukocytes were $\mathrm{GFP}^{+}(86 \%)$, with only a minority of $\mathrm{CD}_{11 \mathrm{~b}}{ }^{+} \mathrm{CD} 45^{\mathrm{dim}}$ microglia being $\mathrm{GFP}^{+}$ (9\%), such that $84 \%$ of $\mathrm{GFP}^{+} \mathrm{CD} 1 \mathrm{~b}^{+}$cells could be classified as leukocytes (CD45 ${ }^{\text {high }}$ ) and only $16 \%$ could be classified as microglia $\left(\mathrm{CD} 45^{\mathrm{dim}}\right)$ at $24 \mathrm{~h}$ (Fig. $\left.3 \mathrm{C}\right)$.

We then asked whether infiltrating or resident $\mathrm{CD} 1 \mathrm{~b}^{+}$populations produced TNF after pMCAo. Histologically, TNF was expressed by both $\mathrm{GFP}^{+}{ }^{+} \mathrm{BM}$-derived leukocytes and $\mathrm{GFP}^{-}$microglia in the area of the infarct (Fig. 3B). In nonchimeric C57BL/6 mice, flow cytometric analysis identified most $\mathrm{TNF}^{+}$cells as $\mathrm{CD} 11 \mathrm{~b}{ }^{+} \mathrm{CD} 45^{\mathrm{dim}}$ microglia, with $4.9 \%$ of this population producing this cytokine, although a small proportion of CD $11 \mathrm{~b}{ }^{+} \mathrm{CD} 45^{\text {high }}$ leukocytes also produced TNF (1.5\%). Overall, we found that $78 \%$ of the

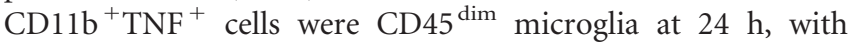
$\mathrm{CD} 11 \mathrm{~b}{ }^{+} \mathrm{CD} 45^{\text {high }}$ leukocytes constituting the remaining $22 \%$ (Fig. 3D). Because both granulocytes and macrophages express CD11b and high levels of CD45, and high numbers of granulocytes are known to infiltrate the infarcted cortex after pMCAo (Gregersen et al., 2000; Clausen et al., 2008), we asked which leukocyte subset was the predominant CD $45^{\text {high }}$ source of TNF. Although granulocytes were abundant $24 \mathrm{~h}$ after pMCAo, double staining for Gr-1 and TNF showed no evidence of coexpression of Gr-1 and TNF (data not shown), thereby identifying TNFexpressing $\mathrm{CD} 11 \mathrm{~b}{ }^{+} \mathrm{CD} 45^{\text {high }}$ cells as macrophages, as also reported recently after pMCAo in BoyJ mice (Clausen et al., 2008). Using flow cytometry, we also observed a number of TCR $\beta^{+}$ T-cells in ischemic and control cortex $(<2000$ cells $)$; however, in line with previous results in BoyJ mice (Clausen et al., 2008), none of these cells expressed TNF (data not shown).

Finally, we compared cellular recruitment and TNF production in GFP-BM-chimeric and nonchimeric C57BL/6 mice. Overall, the profiles of recruitment of $\mathrm{CD} 11 \mathrm{~b}{ }^{+} \mathrm{CD} 45^{\text {high }}$ leukocytes were similar in GFP-BM-chimeric and nonchimeric mice (supplemental Fig. 1 $A, B$, available at www.jneurosci.org as supplemental material). However, as reported recently in the hippocampus (Wirenfeldt et al., 2007), the number of microglia was significantly reduced in the cortex of unmanipulated and ischemic BM-chimeric versus nonchimeric mice (Fig. 3E, unmanipulated mice only). Regardless of this reduction in numbers, microglial cytokine production appeared well preserved, because proportions of TNF-producing $\mathrm{CD} 11 \mathrm{~b}{ }^{+} \mathrm{CD} 45^{\mathrm{dim}}$ and $\mathrm{CD} 11 \mathrm{~b}{ }^{+} \mathrm{CD} 45^{\text {high }}$ cells were similar in GFP-BM-chimeric and nonchimeric mice (Fig. 3F, $24 \mathrm{~h}$ ).

\section{TNF deficiency exacerbates ischemic tissue injury}

To examine the effect of TNF on ischemic tissue injury, we first compared infarct volumes in TNF-KO, wild-type (WT) B6129, and WT C57BL/6 mice $24 \mathrm{~h}$ after pMCAo (Fig. $4 A, B$ ). Importantly, the volume of injury was significantly larger in TNF-KO mice compared with $\mathrm{B} 6129$ and C57BL/6 mice at $24 \mathrm{~h}$ (Fig. $4 A, B)$. We next investigated the volume of injury in TNF-KO and C57BL/ 6 mice with $5 \mathrm{~d}$ survival after pMCAo, thereby also allowing for assessment of behavioral function before and after the ischemic insult (below). The volume of injury was found to be significantly larger in TNF-KO mice compared with C57BL/6 


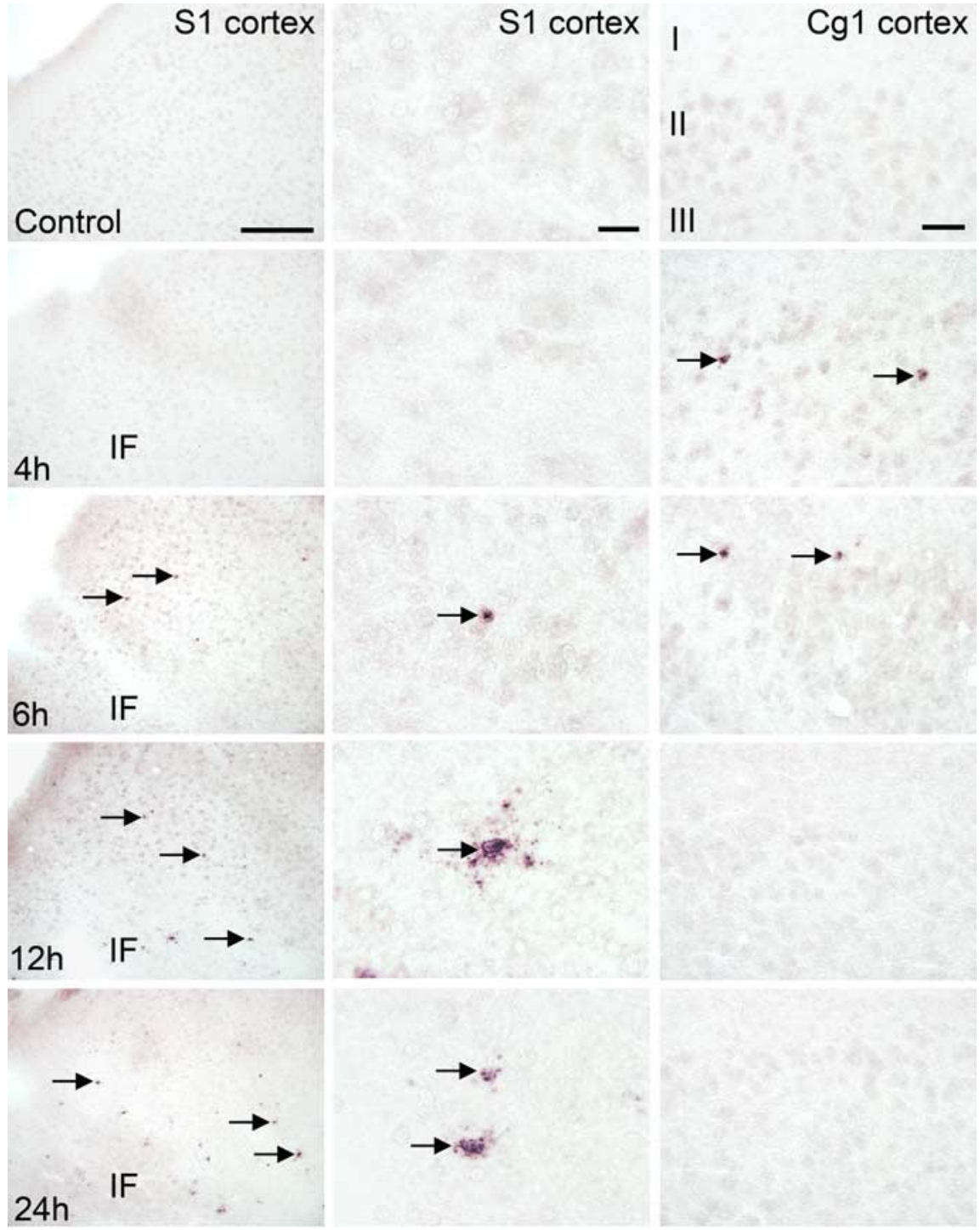

Figure 2. In situ hybridization for TNF mRNA after focal cerebral ischemia. An overview of the distribution of TNF mRNA ${ }^{+}$cells during the first $24 \mathrm{~h}$ after pMCAo in the ipsilateral ischemic cortex (left), and with higher magnifications of somatosensory ( $\mathrm{S} 1_{\text {; }}$ center) and cingulate ( $\mathrm{Cg} 1$; right) cortex, is shown. From $4 \mathrm{~h}$ after pMCAo, low-expressing TNF mRNA ${ }^{+}$cells were mainly located in layers II and III of the cingulate gyrus (arrows in right panel). At $6 \mathrm{~h}$, similar types of TNF mRNA ${ }^{+}$cells were widely distributed throughout the ipsilateral cortex (arrows in middle panel), whereas they at the same time had begun to accumulate at the border of the developing infarct (IF; arrows in left panel). The accumulation was pronounced 12 and $24 \mathrm{~h}$ after pMCAo, when the hybridized cells expressed high levels of TNF mRNA (arrows). A common feature of TNF $\mathrm{mRNA}^{+}$cells was their small elongated to round nuclei compatible with microglial cells or macrophages. Scale bars: left, $200 \mu \mathrm{m}$; middle, $20 \mu \mathrm{m}$; right, $40 \mu \mathrm{m}$.

TNF-KO and B6129 mice was not attributable to differences in vascular anatomy, the circle of Willis in TNF-KO and B6129 mice was analyzed using carbon black perfusion. The circle of Willis was intact in all mice at the level of the anterior and middle cerebral arteries (supplemental Fig. 2A, available at www.jneurosci.org as supplemental material). Most mice also had fully formed PCOM arteries; however, this artery was hypoplastic in one TNF-KO and two B6129 mice and was absent in one TNF-KO and one B6129 mouse (supplemental Fig. $2 A$, available at www.jneurosci. org as supplemental material). Because malformations were observed in both types of mice (supplemental Fig. $2 \mathrm{~A}$, available at www.jneurosci.org as supplemental material), similar PCOM artery scores were obtained in TNF-KO and B6129 mice (supplemental Fig. 2B, available at www. jneurosci.org as supplemental material). Together, these results suggest that TNF deficiency increased infarct volume and that this was not caused by differences in edema formation, brain size, or vascular anatomy between TNF-KO and WT mice.

\section{Behavioral analysis of TNF-deficient and WT mice}

Based on the finding of larger infarct volumes in TNF-KO than WT mice, we investigated whether this might be reflected in the sensory motor function and behavior of the two types of mice. The grip strength test showed that the strength of all four paws were similar $(p=0.19)$ in TNF-KO (231.8 $\pm 44.1 \mathrm{~g} ; n=12)$ and $\mathrm{C} 57 \mathrm{BL} / 6$ $(207.7 \pm 26.1 \mathrm{~g} ; n=9)$ mice before surgery. When we compared the grip strength asymmetry in the front paws (ipsicontralateral) of the TNF-KO mice before surgery $(-5.6 \pm 12.3 \mathrm{~g} ; n=11)$ with the grip strength at 3 and $5 \mathrm{~d}$ after pMCAo, TNF-KO mice showed a trend toward relatively weaker grip strength in the contralateral front paw at both time points $[2.8 \pm 14.3 \mathrm{~g}(p=0.16, t$ test $)$ and $5.2 \pm$

mice also at $5 \mathrm{~d}$ (Fig. $4 C, D$ ). To ensure that this difference could not be ascribed to differences in brain size or edema formation between TNF-KO and WT mice, the volume of the contralateral cortex was estimated and found to be similar in both groups of TNF-KO and WT mice (supplemental Fig. 2C,D, available at www.jneurosci.org as supplemental material). In addition, comparison of mean infarct sizes using an indirect method of infarct volume estimation showed that the infarct constituted $51 \%$ of cortical volume in the TNF-KO mice, compared with $28-37 \%$ in WT mice $24 \mathrm{~h}$ after pMCAo, and $31 \%$ of cortical volume in TNF-KO mice, compared with $23 \%$ in WT mice $5 \mathrm{~d}$ after pMCAo (data not shown). The somewhat smaller volume of injury $5 \mathrm{~d}$ after pMCAo can be ascribed to beginning resorption of the ischemic tissue (Lambertsen et al., 2005).

Finally, to certify that the difference in infarct volume in
$13.7 \mathrm{~g}(p=0.08)$, respectively]. On the contrary, there was no trend in change in the grip strength symmetry in the C57BL/6 mice $(n=7)$ over time (baseline, $2.6 \pm 19.6 \mathrm{~g} ; 3 \mathrm{~d}, 0.9 \pm 5.6 \mathrm{~g}, p=$ $0.74, t$ test; $5 \mathrm{~d},-1.9 \pm 8.9 \mathrm{~g}, p=0.74)$. The grip strength was also measured in the individual hindpaws $5 \mathrm{~d}$ after pMCAo without detection of any asymmetry (ipsi-contralateral) in the average strength between TNF-KO and C57BL/6 (data not shown). However, taken the grip strength lateralization (contralateral weakness) of the front and hindpaws together on d 5, a significant deficiency was observed in the TNF-KO group compared with control (15 and 5 weaker contralateral paws, respectively; $\chi^{2}, p=$ 0.02 ). Furthermore, we tried the rotating pole test (Nygren and Wieloch, 2005) but we were not able to complete the study because of the more frequent unwillingness of the TNF-KO mice to traverse the pole. We finally used a footprint analysis of the hindlimbs to 
record walking patterns during continuous locomotion (Fiore et al., 2004) but did not find any difference between TNF-KO and C57BL/6 mice (data not shown).

\section{Microglia, not macrophages, are responsible for the synthesis of neuroprotective TNF}

Having established that TNF was neuroprotective in cerebral ischemia, we sought to clarify which TNF-producing cell type, the resident microglia or the infiltrating BMderived macrophages, was responsible for the observed neuroprotection. We investigated the volume of ischemic tissue injury in BM-chimeric B6129 (WT) mice grafted with $\mathrm{BM}$ from TNF-KO or WT mice and in BMchimeric $\mathrm{KO}$ mice grafted with $\mathrm{BM}$ from WT or KO mice (Fig. 5A). As expected, TNF mRNA and TNF protein was detected in all combinations of BM-chimeras, except $\mathrm{KO}$ to-KO mice (Fig. 5C,D). Volumetric analysis showed that KO-to-WT mice developed similarly sized infarcts as WT-to-WT mice (Fig. $5 B$ ) and that the volume of injury in these mice was similar to the injury in B6129 mice (Fig. 4B). This showed that TNF produced by BM-derived macrophages had no influence on the size of tissue injury and that tissue injury was unaffected by generation of BM-chimeras. Furthermore, volume estimation showed that the volume of injury in WT-to-KO mice was similar to KO-to-KO mice (Fig. 5B) and TNF-KO mice (Fig. $4 B$ ). This showed that microglial-derived TNF was neuroprotective in cerebral ischemia and emphasized that TNF produced by infiltrating BM-derived macrophages could not compensate for the lack of microglial-derived TNF in the TNF-KO mice. In combination, the results showed that the neuroprotective effect of TNF in mice subjected to focal cerebral ischemia should be attributed to microglial- and not macrophage-derived TNF.

\section{Microglial-derived TNF is \\ neuroprotective through TNF-p55R}

We then asked whether microglial-derived TNF exerted its neuroprotective effect via TNF-p55R or TNF-p75R. Because TNFR mRNA levels are maximally upregulated $5 \mathrm{~d}$ after pMCAo (Lambertsen et al., 2007), we looked for differences at this time. TNF-p55R-KO (R1-KO) mice developed significantly larger infarct volumes compared with TNF-p75R-KO (R2-KO) and C57x129 (Fig. 5E,F) mice, identifying TNF-p55R as the key signaling receptor for neuroprotection. However, we were not able to detect any significant difference in infarct volumes between TNF-p55Rp75R-KO (R-KO) and C57x129 (Fig. 5E,F) mice. This latter observation was reproduced in mice allowed $24 \mathrm{~h}$ of survival (data not shown). As with previous observations (Bruce et al., 1996; Gary et al., 1998; Taoufik et al., 2008), our data show that signaling
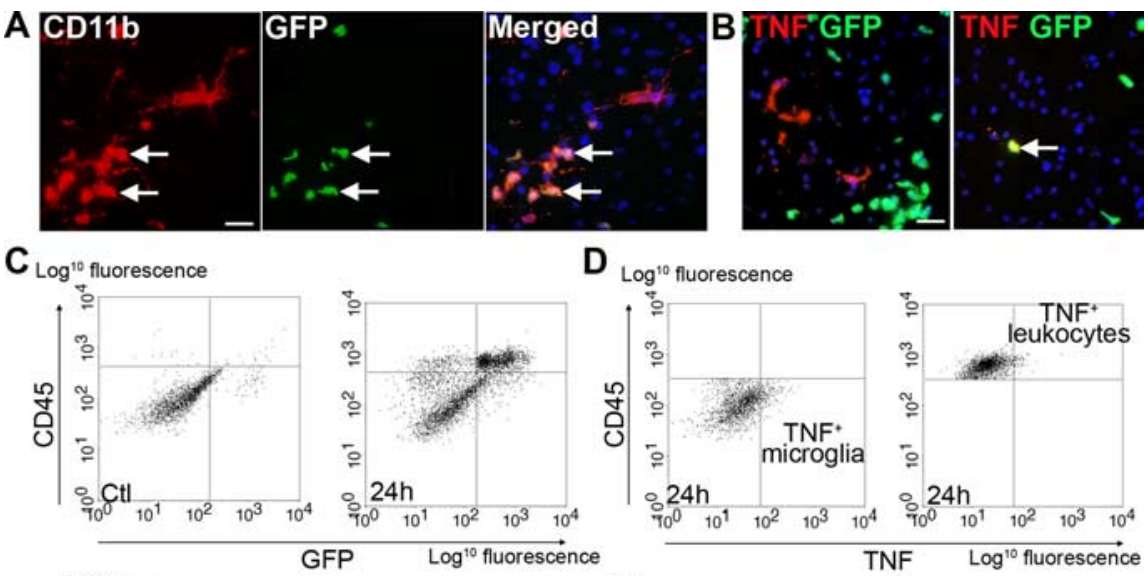

D $\log ^{10}$ fluorescence
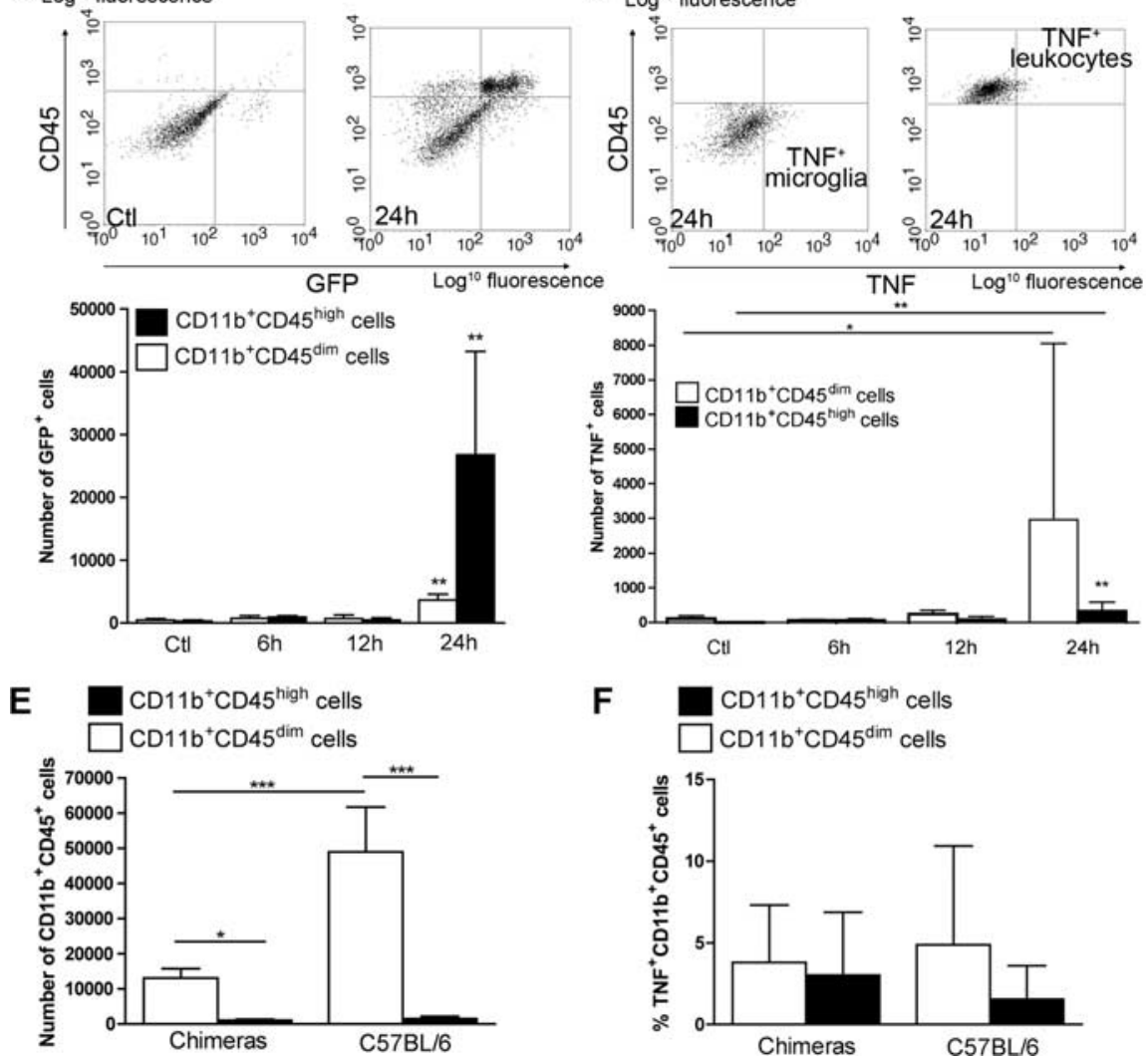

Figure 3. TNF is expressed in microglia and infiltrating leukocytes. $\boldsymbol{A}$, Immunofluorescence photomicrographs of the periinfarct area in a chimeric mouse with infiltrating BM-derived GFP ${ }^{+}$cells (green) stained for CD11b (red) $24 \mathrm{~h}$ after pMCA0. BM-derived, $\mathrm{GFP}^{+}$cells are primarily located within infarct and in peri-infarct regions, and all GFP ${ }^{+}$cells colocalize with CD11b, with the combined green and red fluorescence shown as yellow (arrows). $\boldsymbol{B}$, Immunofluorescence photomicrographs of a chimeric mouse with infiltrating, BM-derived GFP ${ }^{+}$cells (green) stained for TNF (red) $24 \mathrm{~h}$ after pMCA0. TNF is expressed primarily by resident microglia, because most red and green cells do not coincide, but also by infiltrating GFP ${ }^{+}$cells, because GFP ${ }^{+}$cells also stain for TNF (arrow). C, Flow cytometry profiles gated on CD11b ${ }^{+} \mathrm{CD}_{4}{ }^{+}$cells show increased infiltration of GFP ${ }^{+}$cells in ischemic cortex of a BM-chimeric mouse $24 \mathrm{~h}$ after pMCA0, compared with limited numbers of GFP ${ }^{+}$cells in cortex of an unmanipulated mouse. Note that the majority of infiltrating cells in ischemic cortex are GFP ${ }^{+}$CD11b ${ }^{+}$CD45 ${ }^{\text {high }}$ cells. The bar graph shows the number of GFP ${ }^{+} \mathrm{CD} 11 \mathrm{~b}^{+} \mathrm{CD} 45^{\mathrm{dim}}$ and GFP ${ }^{+} \mathrm{CD} 11 \mathrm{~b}{ }^{+} \mathrm{CD} 45^{\text {high }}$ cells and reveals a significant recruitment of $\mathrm{BM}$-derived GFP $^{+}$cells $24 \mathrm{~h}$ after pMCAo (one-way ANOVA followed by Dunnett's multiple comparison test; $n=3-5$ per group). $D$, Flow cytometry profiles showing $\mathrm{TNF}^{+} \mathrm{CD} 11 \mathrm{~b}{ }^{+} \mathrm{CD} 45^{\mathrm{dim}}$ microglia and TNF ${ }^{+} \mathrm{CD} 11 \mathrm{~b}{ }^{+} \mathrm{CD} 45^{\text {high }}$ leukocytes in ischemic cortex $24 \mathrm{~h}$ after pMCAo in a C57BL/6 mouse. Quantification reveals a lesion-specific increase in the total number of TNF ${ }^{+}$cells over time (one-way ANOVA followed by Dunnett's multiple comparison test; $n=3-10$ ). $\boldsymbol{E}$, Quantification of the total number of CD11b ${ }^{+}$CD45 ${ }^{\text {dim }}$ microglia in unmanipulated C57BL/6 and GFP-BM-chimeric mice showed that chimeric mice have significantly fewer microglia in unmanipulated cortex compared with $\mathrm{C57BL} / 6$ mice, whereas the total number of leukocytes was unaffected by irradiation (one-way ANOVA followed by Tukey's test for multiple comparisons; $n=4-7$ ). $\boldsymbol{F}$, Flow cytometric evaluation shows that the proportion of TNF ${ }^{+} \mathrm{CD}_{11 \mathrm{~b}}{ }^{+} \mathrm{CD} 45^{+}$cells was similar in GFP-BM-chimeric and C57BL/6 mice $(n=4-7)$. Results are expressed as mean \pm SD. ${ }^{*} p<0.05 ;{ }^{* *} p>0.01 ;{ }^{* * *} p<0.001$. Scale bars, $20 \mu \mathrm{m}$. Ctl, Control.

through TNF-p55R is neuroprotective in focal cerebral ischemia in mice.

\section{Microglial numbers and TLR2 expression in TNF-deficient and WT mice}

Based on interactions between microglial TNF and TLR2 expression after damage to the CNS (Babcock et al., 2006) and detrimental effects of TLR2 in focal cerebral ischemia (Tang et al., 2007), we next investigated microglial population characteristics 

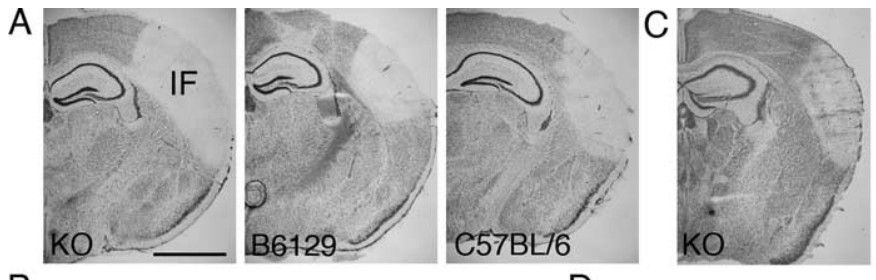

B
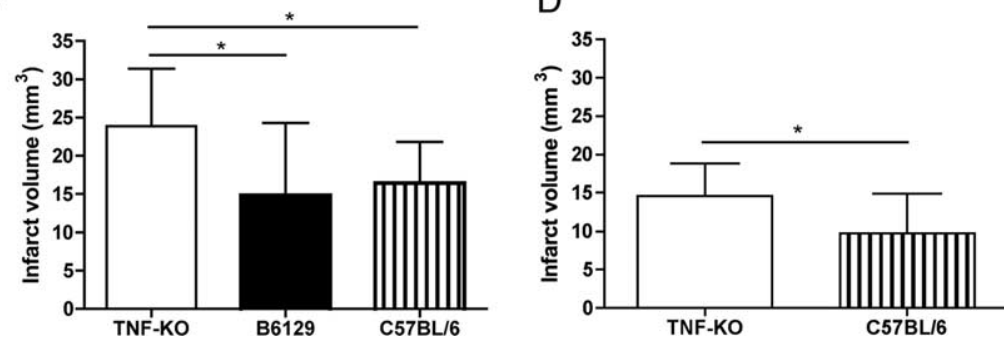

Figure 4. TNF is neuroprotective after permanent focal cerebral ischemia. $A$, Toluidine blue staining of brain sections from TNF-K0, B6129, and C57BL/6 mice $24 \mathrm{~h}$ after pMCA0. IF, Infarct. B, Estimation of cortical infarct volume showed that TNF-K0 mice developed significantly larger infarcts compared with WT B6129 and WT C57BL/6 mice (Mann-Whitney test; $n=14-15)$. C, Toluidine blue staining of brain sections from TNF-KO and C57BL/6 mice $5 \mathrm{~d}$ after pMCA0. D, TNF-KO mice developed significantly larger infarcts compared with WT C57BL/6 mice (Mann-Whitney test; $n=9-12$ ) also at 5 d. Results are expressed as mean \pm SD. ${ }^{*} p<0.05$. Scale bar, $1 \mathrm{~mm}$.

and TLR2 expression in C57BL/6 and TNF-KO mice. Somewhat unexpected, the entire $\mathrm{CD} 11 \mathrm{~b}^{+}$cell population, the vast majority of which were microglia, was significantly reduced in unmanipulated TNF-KO mice (TNF-KO, 63,000 $\pm 10,000, n=5$ vs C57BL/6, 91,000 $\pm 11,000, n=5 ; p<0.01$ ) (Fig. 6A). We additionally found that significantly higher numbers and thereby also proportions of $\mathrm{CD} 11 \mathrm{~b}^{+} \mathrm{CD} 45^{\mathrm{dim}}$ microglial cells expressed TLR2 in unmanipulated C57BL/6 mice (20\%) compared with TNF-KO mice $(6 \%)(p<0.001)$ (Fig. $6 B)$. Interestingly, the ischemia-induced activation of microglia ameliorated the statistical difference in microglial numbers between unmanipulated TNF-KO and C57BL/6 mice (Fig. $6 \mathrm{~A}$ ). In the case of TLR2, the number of TLR2 ${ }^{+}$microglia increased in TNF-KO mice $24 \mathrm{~h}$ after pMCAo to the number of TLR2 ${ }^{+}$microglia observed in C57BL/6 mice (Fig. $6 B$ ). Proportions of TLR2 ${ }^{+}$microglia were increased in both C57BL/6 (29\%) and TNF-KO (18\%) mice versus unmanipulated mice ( $p<0.01$, in both cases), but C57BL/6 mice still presented higher proportions of TLR2 ${ }^{+}$microglia than TNF-KO mice $(p<0.01)$. Together, these data suggest that microglial population size and TLR2 expression were dysregulated in unmanipulated TNF-KO mice but that the insult induced by pMCAo ameliorated the differences between TNF-KO and C57BL/6 mice.

\section{Leukocyte recruitment in TNF-deficient and WT mice}

Because TNF is involved in leukocyte recruitment into CNS (Sedgwick et al., 2000) and microglial TLR2 expression was reduced in unmanipulated TNF-KO mice, we next investigated whether TNF affected leukocyte recruitment and TLR2 expression. As expected, very low numbers of $\mathrm{CD} 11 \mathrm{~b}^{+} \mathrm{CD} 45^{\text {high }}$ leukocytes were observed in unmanipulated $\mathrm{C} 57 \mathrm{BL} / 6$ and TNF-KO mice (Fig. 6A). After pMCAo, a significant ischemiainduced increase in numbers of $\mathrm{CD} 11 \mathrm{~b}^{+} \mathrm{CD} 45^{\text {high }}$ leukocytes occurred in both TNF-KO mice and C57BL/6 mice; however, this increase was significantly higher in TNF-KO mice compared with C57BL/6 mice (Fig. $6 \mathrm{~A}$ ). There was also a tendency toward a higher number of TLR2 ${ }^{+} \mathrm{CD} 11 \mathrm{~b}^{+} \mathrm{CD} 45^{\text {high }}$ leukocytes in the TNF-KO compared with the C57BL/6 mice at $24 \mathrm{~h}$ (Fig. 6B), which, however, did not reach statistical significance.

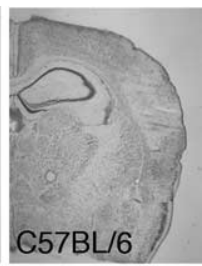

Similarly, the proportions of TLR2 ${ }^{+}$ $\mathrm{CD} 11 \mathrm{~b}^{+} \mathrm{CD} 45^{\text {high }}$ leukocytes were not statistically different after pMCAo in TNF-KO mice (48\%) and C57BL/6 mice $(65 \%)$. Interestingly, the majority of $\mathrm{CD} 11 \mathrm{~b}{ }^{+} \mathrm{CD} 45^{\text {high }}$ leukocytes expressed TLR2 in unmanipulated mice $(\sim 70 \%)$.

Supplementary analysis showed that recruited $\mathrm{CD}_{11 \mathrm{~b}}{ }^{+} \mathrm{CD} 45^{\text {high }}$ leukocytes consisted of a mixture of Gr- $1^{+}$granulocytes and $\mathrm{Gr}-1^{-}$macrophages in both C57BL/6 and TNF-KO mice (supplemental Fig. $3 A$, available at www.jneurosci.org as supplemental material). Significantly higher proportions of macrophages expressed TLR2 than granulocytes in both C57BL/6 mice ( $90 \%$ vs $41 \%$; $p<0.001$ ) and TNF-KO mice $(85 \%$ vs $25 \%$; $p<$ 0.001) $24 \mathrm{~h}$ after pMCAo, although a significantly lower proportion of TLR2 ${ }^{+}$ granulocytes was observed in TNF-KO mice compared with C57BL/6 mice ( $p<$ $0.05)$. Numbers of TLR2 ${ }^{+}$macrophages and TLR2 ${ }^{+}$granulocytes, however, were not significantly different (supplemental Fig. $3 B$, available at www.jneurosci.org as supplemental material).

\section{Effect of TNF on ischemia-induced inflammatory gene expression}

Given the impact of TNF on infarct volume, microglial numbers, and TLR2 expression in unmanipulated mice and leukocyte recruitment after pMCAo, we examined the transcript levels of TNF, and its TNF-p55R and TNF-p75R, and TLR2, CD11b, and IL- $1 \beta$ and iNOS in cerebral hemispheres from unmanipulated TNF-KO and C57BL/ 6 mice and 4 and $24 \mathrm{~h}$ after pMCAo. TNF mRNA levels were statistically elevated in C57BL/6 mice at $24 \mathrm{~h}$, similar to previous demonstration in this study (Fig. $1 B$ ), and undetectable in TNF-KO mice (data not shown). In the case of TNF-p55R, TNF-p75, TLR2, and IL- $1 \beta$, transcript levels were unchanged $4 \mathrm{~h}$ after but elevated $24 \mathrm{~h}$ after pMCAo in both types of mice compared with unmanipulated mice, and with no difference between TNF-KO and C57BL/6 mice (supplemental Fig. $4 A-C, E$, available at www.jneurosci.org as supplemental material). Levels of CD11b mRNA and iNOS mRNA remained at baseline levels at 4 and $24 \mathrm{~h}$ in both types of mice (supplemental Fig. $4 D, F$, available at www.jneurosci.org as supplemental material), as also reported previously (Iadecola et al., 1997; Lambertsen et al., 2007). In conclusion, we found no evidence of a significantly different regulation at the transcript level of the genes investigated within the first $24 \mathrm{~h}$ after pMCAo in TNF-KO compared with C57BL/6 mice.

\section{Effect of TNF on caspase- 3 and NF- $\kappa B$ activation}

Because signaling through the TNF-p55R can lead to both caspase-3 activation (Ferrer and Planas, 2003; Velier et al., 1999) and to NF- $\kappa$ B activation (Schneider et al., 1999; Stephenson et al., 2000), we finally investigated whether TNF deficiency influenced caspase- 3 and NF- $\kappa$ B activation in our model. We initially investigated the presence of activated caspase- $3^{+}$cells in the developing infarct 4, 6, 12, and $24 \mathrm{~h}$ after pMCAo. Activated caspase- $3^{+}$ cells were first present in significant numbers at $24 \mathrm{~h}$ when they were evenly distributed throughout the infarct (Fig. 7). As observed previously $24 \mathrm{~h}$ after pMCAo, activated caspase- 3 was ex- 

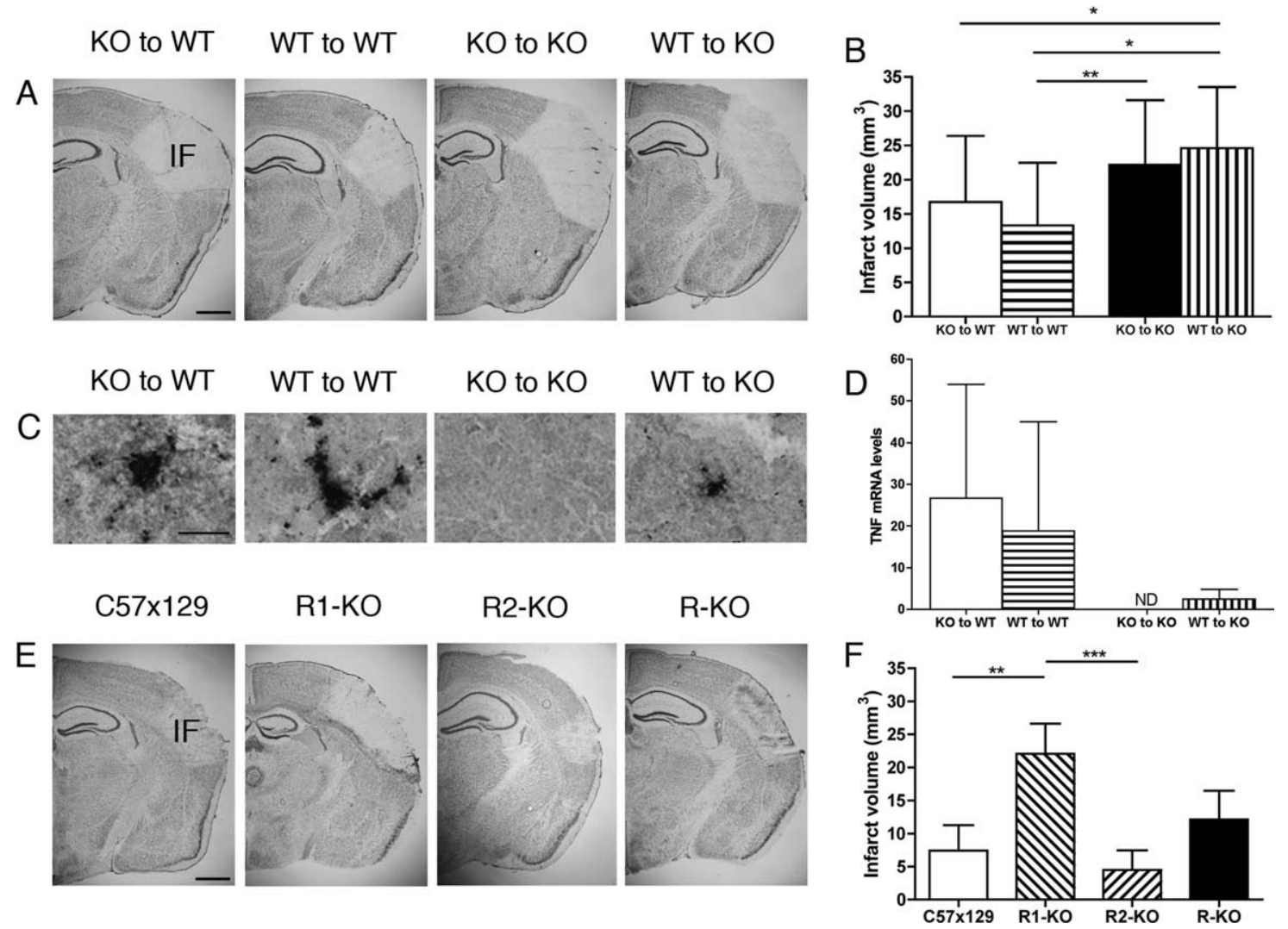

Figure 5. Microglial-derived TNF is neuroprotective through the TNF-p55 receptor. $A$, Toluidine blue staining of sections from BM-chimeric mice $24 \mathrm{~h}$ after pMCA0. B, Estimation of cortical infarct volume in BM-chimeric mice shows that K0-to-WT mice developed injuries similarly sized to those of WT-to-WT mice ( $p=0.26$, Mann-Whitney test; $n=15-20)$, showing that TNF produced by macrophages had no influence on tissue injury after ischemia. Furthermore, WT-to-KO mice developed injuries similarly sized to those of K0-to-KO mice ( $p=0.38$, Mann-Whitney test; $n=18$ ), showing that macrophage-derived TNF could not compensate for the deficiency of microglial-derived TNF in KO mice and demonstrating a neuroprotective role of microglial-derived TNF. C, TNF staining of sections from ischemic BM-chimeric mice $24 \mathrm{~h}$ after pMCAo. TNF protein was present in all BM-chimeric mice, except in K0-to-KO BM-chimeric mice. D, Relative TNF mRNA levels in the ipsilateral, ischemic hemisphere $24 \mathrm{~h}$ after pMCAo from KO-to-WT, WT-to-WT, KO-to-KO, and WT-to-KO mice. TNF mRNA was present in K0-to-WT mice, WT-to-WT mice, and, to a lesser extent, in WT-to-KO mice, but not in KO-to-KO mice. Normalized mRNA levels were calibrated relative to a pool of CDNA from unmanipulated C57BL/6 control mice $(n=4-9)$. $E$, Toluidine blue staining of sections from TNF-p55R-KO (R1-K0), TNF-p75R-KO (R2-K0), TNF-p55p75R-KO (R-K0), and C57x129 mice $5 \mathrm{~d}$ after pMCA0. F, R1-K0 mice developed significantly larger infarcts compared to both R2-K0 and (57x129 mice but not to R-K0 mice $5 \mathrm{~d}$ after pMCA0 (one-way ANOVA followed by Dunn's multiple comparison test; $n=6-7$ ). Results are expressed as mean \pm SD. ${ }^{*} p<0.05$; ${ }^{* *} p<$ $0.01 ;{ }^{* * *} p<0.001$. Scale bars: $\boldsymbol{A}, \boldsymbol{E}, 1 \mathrm{~mm} ; \boldsymbol{C}, 20 \mu \mathrm{m}$. IF, Infarct; ND, none detected.

pressed by CD11b ${ }^{+}$cells (Velier et al., 1999) and not by $\mathrm{NeuN}^{+}$ neurons (Fig. 7), and with no difference in the density of activated caspase- $3^{+}$microglia between TNF-KO $\left(305 \pm 105\right.$ cells $/ \mathrm{mm}^{2}$; $n=7)$ and C57BL/6 mice $\left(238 \pm 108\right.$ cells $\left./ \mathrm{mm}^{2} ; n=9\right)(p=$ 0.21 , Mann-Whitney test).

In the case of NF- $\kappa \mathrm{B}$, Western blotting showed comparable levels of activated NF- $\kappa \mathrm{B}\left({ }^{*} \mathrm{p} 65\right)$ in both nuclear and cytoplasmic protein extracts from unmanipulated TNF-KO and C57BL/6 mice and mice with 6 and $24 \mathrm{~h}$ survival after pMCAo (supplemental Fig. 5, available at www.jneurosci.org as supplemental material), which was supported by observation of similar densities of NF- $\kappa \mathrm{B}^{+}$nuclei within the infarct of TNF-KO and C57BL/6 mice at $24 \mathrm{~h}$ (supplemental Fig. 5, available at www.jneurosci.org as supplemental material). In agreement with previous findings of activation of primarily neuronal NF- $\kappa \mathrm{B}$ after focal cerebral ischemia (Schneider et al., 1999; Zhang et al., 2005), morphology of NF- $\kappa \mathrm{B}^{+}$cells and absence of CD11 $\mathrm{b}^{+} \mathrm{NF}-\kappa \mathrm{B}^{+}$cells pointed at neurons as the prime source of nuclear NF- $\kappa \mathrm{B}$ staining (supplemental Fig. 5, available at www.jneurosci.org as supplemental material). These findings show that there is no simple correlation between TNF-mediated neuroprotection and neuronal caspase-3 or NF- $\kappa \mathrm{B}$ activation after pMCAo, or that other mediators compensated for the absence of TNF.

\section{Discussion}

In this study, we have identified a key role for endogenous microglial-derived TNF, acting through TNF-p55R, in neuroprotection after focal cerebral ischemia in mice. Its significance was underscored by the $\sim 50 \%$ increase in ischemic tissue injury in all mice lacking microglial-derived TNF (i.e., TNF-KO mice, and TNF-KO-to-TNF-KO and WT-to-TNF-KO BM-chimeric mice), compared with the tissue injury in WT mice $24 \mathrm{~h}$ and $5 \mathrm{~d}$ after $\mathrm{pMCAo}$, and by the finding of increased contralateral weakness in TNF-KO mice $5 \mathrm{~d}$ after pMCAo. A neuroprotective role for microglia in focal cerebral ischemia was recently reported for mice subjected to microglial ablation (Lalancette-Hérbert et al., 2007). That microglia play a key role in regulating the brain response to ischemic tissue injury by producing TNF is in line with views that microglia serve important homeostatic functions for neurons (Nimmerjahn et al., 2005; Takahashi et al., 2005) and that TNF acts as a neuromodulator in the brain (Beattie et al., 2002; Stellwagen et al., 2006). Notably, the infarct has fully matured within $6 \mathrm{~h}$ after pMCAo (Gregersen et al., 2000; Lambertsen et al., 2005), implying that small fluctuations in the availability of TNF can have profound implications for neuronal sensitivity to an ischemic insult. In line with previous observations of a delayed 


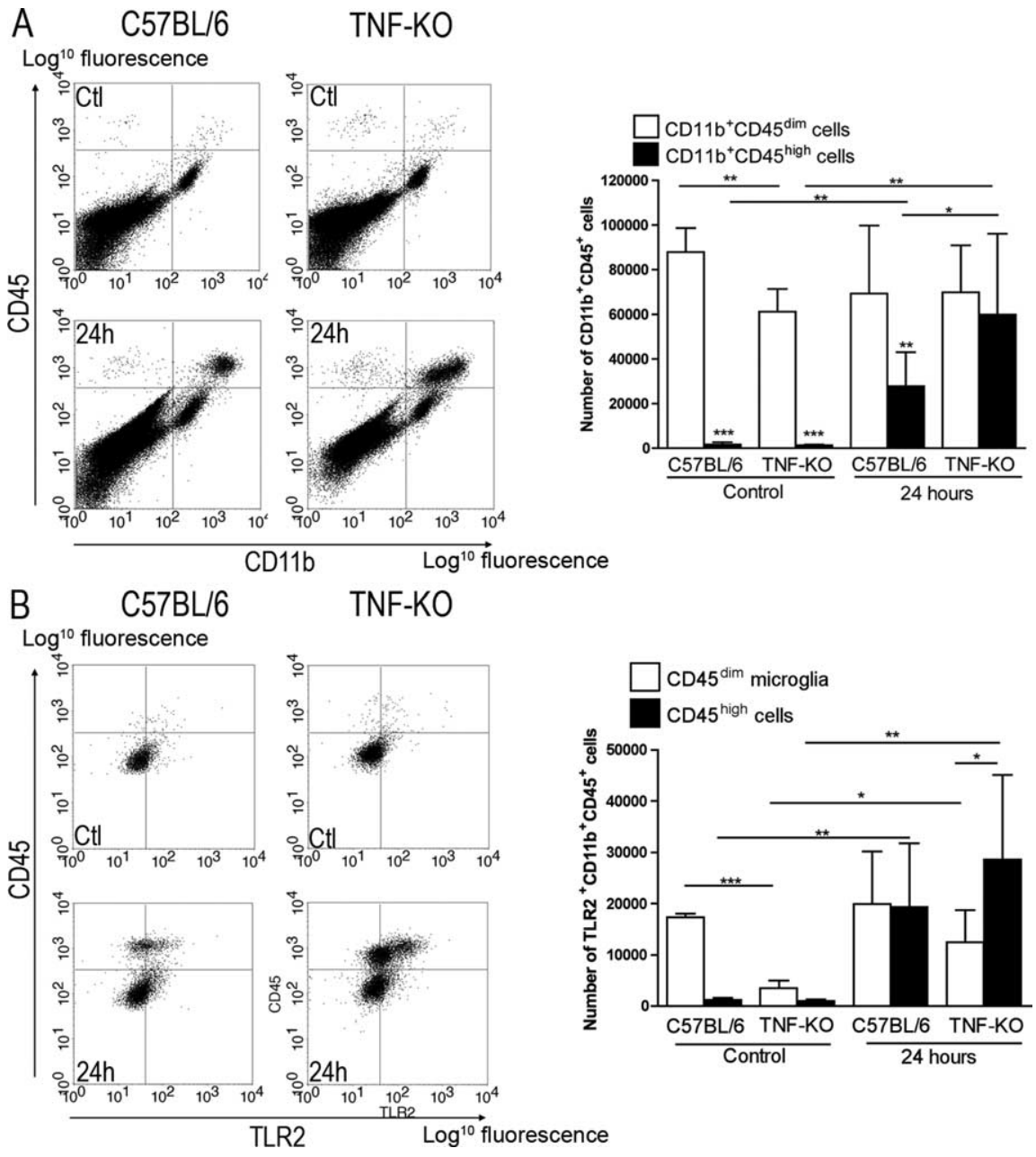

Figure 6. Cellular recruitment and TLR2 expression in TNF-KO mice. A, Flow cytometry profiles gated on FSC/SSC show an increased recruitment of $\mathrm{CD} 11 \mathrm{~b}{ }^{+} \mathrm{CD} 45^{\text {high }}$ leukocytes to the ischemic cortex from C57BL/6 and TNF-KO mice, $24 \mathrm{~h}$ after MCA occlusion relative to unmanipulated mice (Ctl; top right quadrants). Leukocytes were clearly distinguished from CD11b ${ }^{+}$CD45 ${ }^{\mathrm{dim}}$ microglia (bottom right quadrants). Quantification of these populations is shown in the bar graph, which reveals that the recruitment of CD11b ${ }^{+}$CD45 ${ }^{\text {high }}$ leukocytes is significantly larger in TNF-KO compared with C57BL/6 mice after pMCA0. In addition, significantly fewer $\mathrm{CD} 11 \mathrm{~b}{ }^{+} \mathrm{CD} 45^{\mathrm{dim}}$ microglia were isolated from unmanipulated TNF-KO versus C57BL/6 mice, whereas microglial numbers were comparable after pMCA0. B, Flow cytometry profiles gated on $\mathrm{CD} 11 \mathrm{~b}{ }^{+} \mathrm{CD} 45^{+}$cells illustrate the increased recruitment of TLR2 ${ }^{+} \mathrm{CD}_{11 \mathrm{~b}}{ }^{+} \mathrm{CD} 45^{\text {high }}$ cells in TNF-K0 and C57BL/6 mice in the ischemic cortex at $24 \mathrm{~h}$ after pMCAo compared with unmanipulated control (CtI) mice. In comparison, the number of TLR2 ${ }^{+} \mathrm{CD} 11 \mathrm{~b}{ }^{+} \mathrm{CD} 45^{\mathrm{dim}}$ microglia is reduced in unmanipulated TNF-KO compared with unmanipulated $\mathrm{C57BL} / 6$ mice. The bar graph showing the quantitative data confirms these observations. Results are expressed as mean \pm SD; $n=5-8 .{ }^{*} p<0.05 ;{ }^{* *} p<0.01 ;{ }^{* * *} p<0.001$.

recruitment of BM-derived cells into the ischemic brain (Priller et al., 2001), TNF-producing macrophages may simply arrive too late to influence the neurodegenerative process and protect the penumbra from additional damage.

TNF's role in ischemic tissue injury and neurotoxicity is well known (Bruce et al., 1996; Gary et al., 1998; Sullivan et al., 1999; Marchetti et al., 2004; Pradillo et al., 2005). Our observation of increased tissue injury in TNF-KO and TNF-p55R-KO mice is supportive of a neuroprotective role for TNF in the brain and is consistent with studies showing that this effect is mediated through TNF-p55R (Bruce et al., 1996; Gary et al., 1998; Taoufik et al., 2008). TNF-p55R is a high-affinity receptor for soluble TNF, thereby allowing very low concentrations of TNF to have a significant impact on cellular responses (Grell et al., 1998). Thus, constitutive or early microglial TNF may have profound effects on developing ischemic tissue injury. It is, however, similarly well documented that TNF may have neurotoxic effects (Dawson et al., 1996; Barone et al., 1997; Lavine et al., 1998), frequently through TNF-p75R (Fontaine et al., 2002; Marchetti et al., 2004). Although we did not observe significant differences in infarct size between WT and TNF-p75R-KO mice, it may be that TNF is neurotoxic when neuroprotection via TNF-p55R is blocked, because mice lacking both TNF-p75R and TNFp55R did not develop larger infarcts.

In this study, we were able to clearly show that TNF was transcribed in scattered cells with microglial nuclear morphology located in close proximity to $\mathrm{NeuN}^{+}$neurons in the ischemic cortex from 4 to $6 \mathrm{~h}$ after pMCAo. This strongly suggests that it was the resident microglia, not neurons or astrocytes, that were induced by the ischemic insult to transcribe TNF and that they were induced to do so very early after pMCAo in C57BL/6 mice. These observations are also in line with previous observations of early induction of TNF mRNA and protein in GFAP ${ }^{-}$and $\mathrm{CD}_{11 \mathrm{~b}}{ }^{+}$microglia/leukocytes in the ischemic cortex of C57BL/6 and SJL mice (Gregersen et al., 2000; Lambertsen et al., 2005) and demonstrations by others of induction of TNF mRNA in microglial-like cells in the ischemic cortex of rats (Buttini et al., 1996). The fact that we could not detect a significant increase in transcript level in ischemic mice compared with sham-operated or unmanipulated mice $4 \mathrm{~h}$ after pMCAo emphasizes that production of very small amounts of TNF mRNA in scattered cells in the brain may be better detected by in situ hybridization than by quantitative PCR.

Resident microglia and infiltrating macrophages cannot with certainty be distinguished by morphology after ischemic infarction. To identify leukocytes, we therefore used GFP-BM-chimeric mice and flow cytometry, which distinguishes microglia (CD45 ${ }^{\mathrm{dim}}$ ) from macrophages (CD45 high $)$ based on the level of cellular CD45 expression in nonchimeric mice. In line with our recent observations in BoyJ mice subjected to pMCAo (Clausen et al., 2008), we also in the present study found that TNF-producing microglia outnumbered the TNF-synthesizing macrophages at $24 \mathrm{~h}$, thereby also strengthening our in situ hybridization results suggestive that microglia are the first and possibly the only resident CNS cell induced to express TNF mRNA in the ischemic brain. Importantly, we failed to observe synthesis of TNF by Gr-1 ${ }^{+}$granulocytes and TCR $\beta^{+}$T-cells $24 \mathrm{~h}$ after pMCAo, although reports by others have indicated that these cell types may produce TNF, at least in vitro (Lafont et al., 2000; Nguyen et al., 2007).

Radiation BM-chimeric mice have been used extensively for studies of microglial turnover and replacement (Wirenfeldt et al., 2007) and cellular gene therapy (Priller et al., 2001; Mildner et al., 2007). A clear disadvantage of this model is that the recipient is usually subjected to whole-body irradiation before transplanta- 

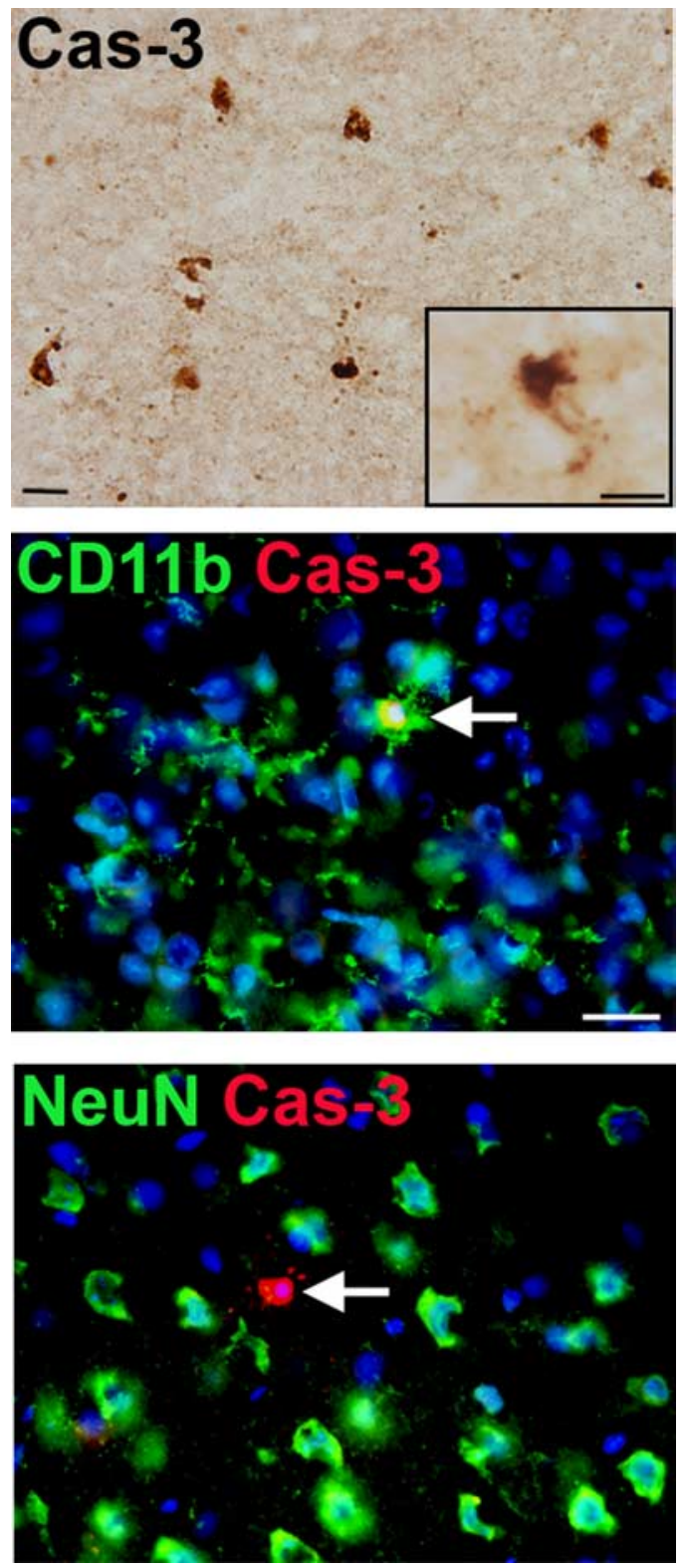

Figure 7. Activation of caspase-3 after permanent focal cerebral ischemia. Immunostaining for activated caspase-3 (Cas-3) cells shows that Cas-3 was expressed throughout the infarct at $24 \mathrm{~h}$ in cells with a microglial morphology (inset) in both TNF-KO and C57BL/6 mice. Immunofluorescence photomicrographs of the peri-infarct area in a $\mathrm{C57BL} / 6$ mouse shows colocalization between Cas-3 (red) and CD11 b ${ }^{+}$cells $24 \mathrm{~h}$ after pMCA0. All Cas- $3^{+}$cells colocalized with CD11b, with the combined green and red fluorescence shown as yellow (arrow). Immunofluorescence photomicrographs of the infarct in a $57 \mathrm{BL} / 6$ mouse stained for Cas-3 (red, arrow) and NeuN (green) $24 \mathrm{~h}$ after MCA occlusion are shown. Cas- 3 is not expressed by neurons, because red fluorescence and green fluorescence do not coincide. Scale bars: $20 \mu \mathrm{m}$; insert, $10 \mu \mathrm{m}$.

tion, which might induce microglial activation or cell death (Mildner et al., 2007; Wirenfeldt et al., 2007) and lead to aberrant recruitment and microglial transformation of BM-derived cells. Indeed, a reduction in the microglial population in GFP-BMchimeras to $\sim 30 \%$ of that observed in normal mice has recently been reported by our laboratory (Wirenfeldt et al., 2007; Clausen et al., 2008), in parallel with reports by others showing that microglial turnover by BM-derived cells is, to a large extent, a radiation-induced and not a naturally occurring phenomenon (Mildner et al., 2007). Although, a BM-chimeric mouse per definition is not a normal mouse, we found that the microglial- macrophage response to focal cerebral ischemia in BM-chimeric and nonchimeric mice was comparable in terms of proportions of TNF-producing microglia and macrophages. These data are consistent with findings by others that irradiation does not compromise or exacerbate the innate immune response in BMchimeric mice (Turrin et al., 2007).

Recovery of fewer microglia from the cortex of TNF-KO compared with WT mice was unexpected. This was partly attributable to our finding of comparable neocortical volumes and CD11b mRNA levels and partly because we, despite reports about a stimulatory role of TNF on microglial proliferation in vitro (Théry and Mallat, 1993), failed to observe significant differences in microglial numbers in both unmanipulated hippocampus and perforant pathway-deafferented dentate gyrus in TNF-KO, TNFp55Rp75R-KO, TNF-p55R-KO, and WT mice (Babcock et al., 2006; Fenger et al., 2006). Although undetectable in the volumetric data in this study, and in conventional microglial stainings, we cannot exclude that the cellular composition and fine structure of neocortex may differ between TNF-KO and WT mice, or that there are regional adjustments of microglia as a result of different homeostatic requirements by cortical and hippocampal neurons. Alternatively, the reduced recovery of microglia may reflect inherent differences in viability or difficulties in isolation during the tissue processing procedure used for flow cytometry. However, such differences were not observed $24 \mathrm{~h}$ after pMCAo, when microglial numbers were similar in TNF-KO and WT mice. In support of our findings, significantly fewer activated microglia have been observed in the striatum and substantia nigra of TNF-KO mice in a model for Parkinson's disease (Zhao et al., 2007).

TLR2 belongs to a family of pattern recognition receptors implicated in innate responses to tissue injury (Gordon, 2002). In the CNS of genetically normal mice, TLR2 is expressed on resting and activated microglia (Babcock et al., 2006). TLR2 signaling is required for TNF production in vitro (Aravalli et al., 2005) and can control inflammation via TNF (Letiembre et al., 2005; Babcock et al., 2006). Like TNF, TLR2 is involved in cerebral ischemia (Tang et al., 2007). The reduced number of TLR $2^{+}$microglia in TNF-KO mice may be explained by recent findings that TNF enhances TLR2 expression in primary microglia (Syed et al., 2007). Importantly, however, TNF-deficient microglia remained capable of upregulating TLR2 expression, because numbers of $\mathrm{TLR}^{+}{ }^{+}$microglia were similar in TNF-KO and WT mice $24 \mathrm{~h}$ after pMCAo. Macrophages and granulocytes were also found to express TLR2, although numbers of TLR $2{ }^{+}$leukocytes were similar between TNF-KO and C57BL/6 mice. This was likely attributable to the overall increase in $\mathrm{CD} 11 \mathrm{~b}{ }^{+} \mathrm{CD} 45^{\text {high }}$ leukocytes observed in TNF-KO mice after pMCAo. The $\sim 50 \%$ increase in leukocyte infiltration observed might simply reflect the $50 \%$ larger infarcts in TNF-KO mice compared with C57BL/6 mice.

Our finding, that microglial-derived TNF is essential for neuroprotection after pMCAo shows that microglia promote survival of endangered neurons, rather than neuronal loss. Insufficient numbers of microglia appear to be detrimental at onset of ischemic stroke, because the increased vulnerability of TNF-KO mice was associated with reduced microglial numbers. Microglial expression of TLR2 was also impaired in unmanipulated TNF-KO mice. Although existing literature shows that TLR2-KO mice develop smaller infarcts than WT mice (Tang et al., 2007), this might be attributed to TLR2 signaling in neurons. The effect of a selective reduction of microglial TLR2 on neurons is not known. These observations indicate that microglia, through TNF synthesis, regulate their own survival and functional profile. 
Collectively, the present findings identify a neuroprotective role for microglial-derived TNF in the acute phase after focal cerebral ischemia and point to microglia as key regulators of neuronal survival after ischemic tissue injury.

\section{References}

Aravalli RN, Hu S, Rowen TN, Palmquist JM, Lokensgard JR (2005) Cutting edge: TLR2-mediated proinflammatory cytokine and chemokine production by microglial cells in response to herpes simplex virus. J Immunol 175:4189-4193.

Babcock AA, Wirenfeldt M, Holm T, Nielsen HH, Dissing-Olesen L, ToftHansen H, Millward J, Landmann R, Rivest S, Finsen B, Owens T (2006) Toll-like receptor 2 signaling in response to brain injury: an innate bridge to neuroinflammation. J Neurosci 26:12826-12837.

Barone FC, Arvin B, White RF, Miller A, Webb CL, Willette RN, Lysko PG, Feuerstein GZ (1997) Tumor necrosis factor-alpha. A mediator of focal ischemic brain injury. Stroke 28:1233-1244.

Beattie EC, Stellwagen D, Morishita W, Bresnahan JC, Ha BK, von Zastrow M, Beattie MS, Malenka RC (2002) Control of synaptic strength by glial TNFalpha. Science 22:2282-2285.

Bruce AJ, Boling W, Kindy MS, Peschon J, Kraemer PJ, Carpenter MK, Holtsberg FW, Mattson MP (1996) Altered neuronal and microglial responses to excitotoxic and ischemic brain injury in mice lacking TNF receptors. Nat Med 2:788-794.

Buttini M, Appel K, Sauter A, Gebicke-Haerter PJ, Boddeke HW (1996) Expression of tumor necrosis factor alpha after focal cerebral ischaemia in the rat. Neuroscience 71:1-16.

Clausen BH, Lambertsen KL, Meldgaard M, Finsen B (2005) A quantitative in situ hybridization and polymerase chain reaction study of microglialmacrophage expression of interleukin-1beta mRNA following permanent middle cerebral artery occlusion in mice. Neuroscience 132:879-892.

Clausen BH, Lambertsen KL, Babcock AA, Holm TH, Dagnaes-Hansen F, Finsen B (2008) Interleukin-1beta and tumor necrosis factor-alpha are expressed by different subsets of microglia and macrophages after ischemic stroke in mice. J Neuroinflamm 5:46.

Crack PJ, Taylor JM, Ali U, Mansell A, Hertzog PJ (2006) Potential contribution of NF- $\kappa$ B in neuronal cell death in the glutathione peroxidase-1 knockout mouse in response to ischemia-reperfusion injury. Stroke 37:1533-1538.

Dawson DA, Martin D, Hallenbeck JM (1996) Inhibition of tumor necrosis factor-alpha reduces focal cerebral ischemic injury in the spontaneously hypersensitive rat. Neurosci Lett 218:41-44.

Dziewulska D, Mossakowski MJ (2003) Cellular expression of tumor necrosis factor a and its receptors in human ischemic stroke. Clin Neuropathol 22:35-40.

Fenger C, Drojdahl N, Wirenfeldt M, Sylvest L, Jorgensen OS, Meldgaard M, Lambertsen KL, Finsen B (2006) Tumor necrosis factor and its p55 and p75 receptors are not required for axonal lesion-induced microgliosis in mouse fascia dentata. Glia 54:591-605.

Ferrer I, Planas AM (2003) Signaling of cell death and cell survival following focal cerebal ischemia: life and death struggle in the penumbra. J Neuropathol Exp Neurol 62:329-339.

Fiore C, Inman DM, Hirose S, Noble LJ, Igarashi T, Compagnonei A (2004) Treatment with the neurosteroid dehydroepiandrosterone promotes recovery of motor behavior after moderate contusive spinal cord injury in the mouse. J Neurosci Res 75:391-400.

Fontaine V, Mohand-Said S, Hanoteau N, Fuchs C, Pfizenmaier K, Eisel U (2002) Neurodegenerative and neuroprotective effects of tumor necrosis factor (TNF) in retinal ischemia: opposite roles of TNF receptor 1 and TNF receptor 2. J Neurosci 22:RC216(1-7).

Ford AL, Goodsal AL, Hickey WF, Sedwick JD (1995) Normal adult ramified microglia separated from other central-nervous-system macrophages by flow cytometric sorting. Phenotypic differences defined and direct ex-vivo antigen presentation to myelin basic protein-reactive $\mathrm{Cd} 4(+)$ T-cells compared. J Immunol 154:4309-4321.

Gao B, Kilic E, Baumann CR, Hermann DM, Bassetti CL (2008) Gammahydroxybutyrate accelerates functional recovery after focal cerebral ischemia. Cerebrovasc Dis 26:413-419.

Gary DS, Bruce-Keller AJ, Kindy MS, Mattson MP (1998) Ischemic and excitotoxic brain injury is enhanced in mice lacking the p55 tumor necrosis factor receptor. J Cereb Blood Flow Metab 18:1283-1287.
Gordon S (2002) Pattern recognition receptors: doubling up for the innate immune response. Cell 111:927-930.

Gregersen R, Lambertsen K, Finsen B (2000) Microglia and macrophages are the major source of tumor necrosis factor in permanent middle cerebral artery occlusion in mice. J Cereb Blood Flow Metab 20:53-65.

Grell M, Wajant H, Zimmermann G, Scheurich P (1998) The type 1 receptor $(\mathrm{CD} 120 \mathrm{a})$ is the high-affinity receptor for soluble tumor necrosis factor. Proc Natl Acad Sci USA 95:570-575.

Hallenbeck JM (2002) The many faces of tumor necrosis factor in stroke. Nat Med 8:1363-1368.

Iadecola C, Zhang F, Casey R, Nagayama M, Ross ME (1997) Delayed reduction of ischemic brain injury and neurological deficits in mice lacking the inducible nitrix oxide synthase gene. J Neurosci 17:9157-9164.

Lafont V, Liautard J, Gross JP, Favero J (2000) Tumor necrosis factor-alpha production is differently regulated in gamma delta and alpha beta human T lymphocytes. J Biol Chem 275:19282-19287.

Lalancette-Hérbert M, Gowing G, Simard A, Weng YC, Kriz J (2007) Selective ablation of proliferating microglial cells exacerbates ischemic injury in the brain. J Neurosci 27:2596-2605.

Lambertsen KL, Meldgaard M, Ladeby R, Finsen B (2005) A quantitative study of microglial-macrophage synthesis of tumor necrosis factor during acute and late focal cerebral ischemia in mice. J Cereb Blood Flow Metab 25:119-135.

Lambertsen KL, Clausen BH, Fenger C, Wulf H, Owens T, Dagnaes-Hansen F, Meldgaard M, Finsen B (2007) Microglia and macrophages express tumor necrosis factor receptor p75 following middle cerebral artery occlusion in mice. Neuroscience 144:934-949.

Lavine SD, Hosman FM, Zlokovic BV (1998) Circulating antibody against tumor necrosis factor-alpha protects rat brain from reperfusion injury. J Cereb Blood Flow Metab 18:52-58.

Letiembre M, Echchannaoui H, Ferracin F, Rivest S, Landmann R (2005) Toll-like receptor-2 deficiency is associated with enhanced brain TNF gene expression during pneumococcal meningitis. J Neuroimmunol 168:21-33.

Lin TN, He YY, Wu G, Khan M, Hsu CY (1993) Effect of brain edema on infarct volume in a focal cerebral ischemia model in rats. Stroke 24:117-121.

Liu T, Clark RK, McDonnell PC, Young PR, White RF, Barone FC, Feuerstein GZ (1994) Tumor necrosis factor-alpha expression in ischemic neurons. Stroke 25:1481-1488.

Marchetti L, Klein M, Schlett K, Pfizenmaier K, Eisel UL (2004) Tumor necrosis factor (TNF)-mediated neuroprotection against glutamateinduced excitotoxicity is enhanced by $\mathrm{N}$-methyl-D-aspartate receptor activation. Essential role of a TNF receptor 2-mediated phosphatidylinositol 3-kinase-dependent NF-kappa B pathway. J Biol Chem 279:32869-32881.

Meldgaard M, Fenger C, Lambertsen KL, Pedersen MD, Ladeby R, Finsen B (2006) Validation of two reference genes for mRNA level studies of murine disease models in neurobiology. J Neurosci Methods 156:101-110.

Mildner A, Schmidt H, Nitsche M, Merkler D, Hanisch UK, Mack M, Heikenwalder M, Brück W, Priller J, Prinz M (2007) Microglia in the adult brain arise from Ly- $6 \mathrm{C}^{\text {hi }} \mathrm{CCR} 2{ }^{+}$monocytes only under defined host conditions. Nat Neurosci 10:1544-1553.

Nawashiro H, Tasaki K, Ruetzler CA, Hallenbeck JM (1997) TNF-alpha pretreatment induces protective effects against focal cerebral ischemia in mice. J Cereb Blood Flow Metab 17:483-490.

Nguyen HX, O’Barr TJ, Anderson AJ (2007) Polymorphonuclear leukocytes promote neurotoxicity through release of matrix metalloproteinases, reactive oxygen species, and TNF-alpha. J Neurochem 102:900-912.

Nimmerjahn A, Kirchhoff F, Helmchen F (2005) Resting microglial cells are highly dynamic surveillants of brain parenchyma in vivo. Science 308:1314-1318.

Nygren J, Wieloch T (2005) Enriched environment enhances recovery of motor function after focal ischemia in mice, and downregulates the transcription factor NGFI-A. J Cereb Blood Flow Metab 25:1,625-1:633.

Pradillo JM, Romera C, Hurtado O, Cárdenas A, Moro MA, Leza JC, Dávalos A, Castillo J, Lorenzo P, Lizasoain I (2005) TNFR1 upregulation mediates tolerance after brain ischemic preconditioning. J Cereb Blood Flow Metab 25:193-203.

Priller J, Flugel A, Wehner T, Boentert M, Haas CA, Prinz M, Fernandez-Klett F, Prass K, Bechmann I, de Boer BA, Frotscher M, Kreutzberg GW, Persons DA, Dirnagl U (2001) Targeting gene-modified hematopoietic 
cells to the central nervous system: use of green fluorescent protein uncovers microglial engraftment. Nat Med 7:1356-1361.

Pronichev IV, Lenkov DN (1998) Functional mapping of the motor cortex of the white mouse by a microstimulation method. Neurosci Behav Physiol 28:80-85.

Schneider A, Martin-Villalba A, Weih F, Vogel J, Wirth T, Schwaninger M (1999) NF- $\kappa$ B is activated and promotes cell death in focal cerebral ischemia. Nat Med 5:554-559.

Sedgwick JD, Schwender S, Imrich H, Dorries R, Butcher GW, Termeulen V (1991) Isolation and direct characterization of resident microglial cells from the normal and inflammed central nervous system. Proc Natl Acad Sci U S A 88:7438-7442.

Sedgwick JD, Riminton DS, Cyster JG, Körner H (2000) Tumor necrosis factor: a master-regulator of leukocyte movement. Immunol Today 21:110-113.

Sotgiu S, Zanda B, Marchetti B, Fois ML, Arru G, Pes GM, Salaris FS, Arru A, Pirisi A, Rosati G (2006) Inflammatory biomarkers in blood of patients with acute brain ischemia. Eur J Neurol 13:505-513.

Stellwagen D, Malenka RC (2006) Synaptic scaling is mediated by glial TNFalpha. Nature 440:1054-1059.

Stephenson D, Yin T, Smalstig EB, Hsu MA, Panetta J, Little S, Clemens J (2000) Transcription factor nuclear factor-kappa B is activated in neurons after focal cerebral ischemia. J Cereb Blood Flow Metab 20:592-603.

Sullivan PG, Bruce-Keller AJ, Rabchevsky AG, Christakos S, Clair DK, Mattson MP, Scheff SW (1999) Exacerbation of damage and altered NF- $\kappa$ B activation in mice lacking tumor necrosis factor receptors after traumatic brain injury. J Neurosci 19:6248-6256.

Syed MM, Phulwani NK, Kielian T (2007) Tumor necrosis factor-alpha (TNF-alpha) regulates Toll-like receptor 2 (TLR2) expression in microglia. J Neurochem 103:1461-1471.

Takahashi K, Rochford CD, Neumann H (2005) Clearance of apoptotic neurons without inflammation by microglial triggering receptor expressed on myeloid cells-2. J Exp Med 201:647-657.

Tang SC, Arumugam TV, Xu X, Cheng A, Mughal MR, Jo DG, Lathia JD, Siler DA, Chigurupati S, Ouyang X, Magnus T, Camandola S, Mattson MP (2007) Pivotal role for neuronal Toll-like receptors in ischemic brain injury and functional defecits. Proc Natl Acad Sci U S A 104:13798-13803.

Taoufik E, Petit E, Divoux D, Tseveleki V, Mengozzi M, Roberts ML, Valable S, Ghezzi P, Quackenbush J, Brines M, Cerami A, Probert L (2008) TNF receptor I sensitizes neurons to erythropoietin- and VEGF-mediated neu- roprotection after ischemic and excitotoxic injury. Proc Natl Acad Sci U S A 105:6,185-6:190.

Tarkowski E, Rosengren L, Blomstrand C, Wikkelsö C, Jensen C, Ekholm S, Tarkowski A (1997) Intrathecal release of pro- and anti-inflammatory cytokines during stroke. Clin Exp Immunol 110:492-499.

Théry C, Mallat M (1993) Influence of interleukin-1 and tumor necrosis factor alpha on the growth of microglial cells in primary cultures of mouse cerebral cortex: involvement of colony-stimulating factor 1. Nat Neurosci Lett 150:195-199.

Turrin NP, Rivest S (2006) Tumor necrosis factor alpha but not interleukin 1 beta mediates neuroprotection in response to acute nitric oxide excitotoxicity. J Neurosci 26:143-151.

Turrin NP, Plante MM, Lessard M, Rivest S (2007) Irradiation does not compromise or exacerbate the innate immune response in the brains of mice that were transplanted with bone marrow stem cells. Stem Cells 25:3,165-3:172

Velier JJ, Ellison JA, Kikly KK, Spera PA, Barone FC, Feuerstein GZ (1999) Caspase- 8 and caspase- 3 are expressed by different populations of cortical neurons undergoing delayed cell death after focal stroke in the rat. J Neurosci 19:5932-5941.

Wang H, Xu L, Venkatachalam S, Trzaskos JM, Friedman SM, Feuerstein GZ, Wang X (2001) Differential regulation of IL-1beta and TNF-alpha RNA expression by MEK1 inhibitor after focal cerebral ischemia in mice. Biochem Biophys Res Commun 286:869-874.

Wang X, Feuerstein GZ, Xu L, Wang H, Schumacher WA, Ogletree ML, Taub R, Duan JJ, Deciccio CP, Liu RQ (2004) Inhibition of tumor necrosis factor-alpha-converting enzyme by a selective antagonist protects brain from focal ischemic injury in rats. Mol Pharmacol 65:890-896.

Wirenfeldt M, Dissing-Olesen L, Babcock AA, Nielsen M, Meldgaard M, Zimmer J, Azcoitia I, Leslie RGQ, Dagnaes-Hansen F, Finsen B (2007) Population control of resident and immigrant microglia by mitosis and apoptosis. Am J Pathol 171:617-631.

Zaremba J, Losy J (2001) Early TNF-alpha levels correlate with ischaemic stroke severity. Acta Neurol Scand 104:288-295.

Zhang W, Potrovita I, Tarabin V, Hermann O, Beer V, Weih F, Schneider A, Schwaninger M (2005) Neuronal activation of NF-kappaB contributes to cell death in cerebral ischemia. J Cereb Blood Flow Metab 25:30-40.

Zhao C, Ling Z, Newman MB, Bhatia A, Carvey PM (2007) TNF- $\alpha$ knockout and minocycline treatment attenuates blood-brain barrier leakage in MPTP-treated mice. Neurobiol Dis 26:36-46. 